\title{
Cereal landraces genetic resources in worldwide GeneBanks. A review
}

\author{
Miguel A. A. Pinheiro de Carvalho • Penelope J. Bebeli • \\ Eliseu Bettencourt • Graça Costa • Sonia Dias • \\ Teresa M. M. Dos Santos • Jan J. Slaski
}

Accepted: 5 March 2012 / Published online: 24 April 2012

(C) INRA and Springer-Verlag, France 2012

\begin{abstract}
Since the dawn of agriculture, cereal landraces have been the staples for food production worldwide, but their use dramatically declined in the 2 nd half of the last century, replaced by modern cultivars. In most parts of the world, landraces are one of the most threatened components of agrobiodiversity, facing the risk of genetic erosion and extinction. Since landraces have a tremendous potential in the development of new cultivars adapted to changing environmental conditions, GeneBanks holding their genetic resources potentially play an important role in supporting
\end{abstract}

Eliseu Bettencourt is currently on leave of absence.

M. A. A. P. de Carvalho - G. Costa - T. M. M. D. Santos ·

J. J. Slaski $(\bowtie)$

ISOPlexis Germplasm Bank, University of Madeira,

Campus da Penteada,

9000-390 Funchal, Portugal

e-mail: jan.slaski@albertainnovates.ca

\section{P. J. Bebeli}

Department of Plant Breeding and Biometry,

Agricultural University of Athens,

Iera Odos 75,

Athens 11855, Greece

E. Bettencourt

Genetic Resources, Ecophysiology and Plant Breeding Unit, Instituto Nacional de Investigação Agrária e Veterinária

(INIAV, I. P.),

Quinta do Marquês,

2784-505 Oeiras, Portugal

S. Dias

Bioversity International,

Via dei Tre Denari 472/a,

00057 Maccarese (Rome), Italy

J. J. Slaski

Bioresource Technologies, Alberta Innovates Technology Futures, Vegreville, Alberta T9C 1T4, Canada sustainable agriculture. This work reviews the current knowledge on cereal landraces maintained in GeneBanks and highlights the strengths and weaknesses of existing information about their taxonomy, origin, structure, threats, sampling methodologies and conservation and GeneBanks' documentation and management. An overview of major collections of cereal landraces is presented, using the information available in global metadatabase systems. This review on winter cereal landrace conservation focuses on: (1) traditional role of GeneBanks is evolving beyond their original purpose to conserve plant materials for breeding programmes. Today's GeneBank users are interested in landraces' history, agro-ecology and traditional knowledge associated with their use, in addition to germplasm traits. (2) GeneBanks therefore need to actively share their germplasm collections' information using different channels, to promote unlimited and effective use of these materials for the further development of sustainable agriculture. (3) Access to information on the 7.4 million accessions conserved in GeneBanks worldwide, of which cereal accessions account for nearly $45 \%$, particularly information on cereal landraces ( $24 \%$ of wheat, $23 \%$ of barley, $14 \%$ of oats and $29 \%$ of rye accessions), is often not easily available to potential users, mainly due to the lack of consistent or compatible documentation systems, their structure and registration. (4) Enhancing the sustainable use of landraces maintained in germplasm collections through the effective application of recent advances in landrace knowledge (origin, structure and traits) and documentation using the internet tools and data providing networks, including the use of molecular and biotechnological tools for the material screening and detection of agronomic traits. (5) Cereal landraces cannot be exclusively conserved as seed samples maintained under ex situ conditions in GeneBanks. The enormous contribution of farmers in maintaining the crop and landraces 
diversity is recognised. Sharing of benefits and raising awareness of the value of cereal landraces are the most effective ways to promote their conservation and to ensure their continued availability and sustainable use. (6) Evaluation of costs and economic benefits attributed to sustainable use of cereal landraces conserved in the GeneBanks requires comprehensive studies conducted on a case-by-case basis, that take into consideration species/crop resources, conservation conditions and quality and GeneBank location and functions.

Keywords GeneBanks · Cereal landraces · Wheat · Rye · Barley · Oats · Origin · Conservation · Documentation systems $\cdot$ Germplasm

\section{Abbreviations}

AEGRO

ARS
AVRDC
AWCC
CENARG
CGN
CIMMYT
CGIAR
CBD
CWR
DSA
EADB
EC
ECPGR

EURISCO

ESDB

EWDB

FAO

GBIMS

GFG

GRIN

GPA

GBIF

IBCC ICGR-CAAS and On Farm Concepts

Agricultural Research Services

World Vegetable Centre

Australian Winter Cereals Collection

EMBRAPA Recursos Genéticos e

Biotecnologia

Centre for Genetic Resources (The

Netherlands)

The International Maize and Wheat Improvement Centre

The Consultative Group on International

Agricultural Research

Convention on Biological Diversity

Crop wild relatives

Data Sharing Agreement

European Avena Database

European Commission

European Cooperative Programme for Plant

Genetic Resources

European Plant Genetic Resources Search

Catalogue

European Secale Database

European Wheat Database

Food and Agriculture Organization of the United Nations

Indian GeneBank Information Management System

German Federal GeneBank

Germplasm Resources Information

Network

Global Plan of Action

Global Biodiversity Information Facility

International Barley Core Collection

Institute of Crop Germplasm Resources,

Chinese Academy of Agricultural Sciences
ICARDA

IC

ICIS

IBPGR

IPGRI

IPK

IHAR

ITPGRFA

$\mathrm{MoU}$

NBPGR

NIs

NIAS

International Centre for Agricultural

Research in the Dry Areas

Institute Code

International Crop Information System

International Board for Plant Genetic

Resources

International Plant Genetic Resources

Institute (now Bioversity International)

Leibniz Institute of Plant Genetics and

Crop Plant Research (Germany)

Plant Breeding and Acclimatization

Institute (Poland)

International Treaty on Plant Genetic

Resources for Food and Agriculture

Memorandum of Understanding

National Bureau of Plant Genetic

Resources (India)

European National Inventories

National Institute of Agrobiological

Sciences

NordGen Nordic Genetic Resources Centre

NSGC

PGRC

PGR

PGRFA

SEEDNet

SGRP

National Small Grains Germplasm

Research Facility (USA)

Plant Gene Resources of Canada

Plant genetic resources

Plant genetic resources for food and agriculture

South-East European Development

Network on Plant Genetic Resources

Government of The Netherlands and the

System-wide Genetic Resources

Programme

SINGER System-wide Information Network for

Genetic Resources

USDA US Department of Agriculture

US NPGS US National Plant Germplasm System

VIR

WIEWS World Information and Early Warning

System on Plant Genetic Resources for

Food and Agriculture.
Contents

1. Introduction. . . . . . . . . . . . . . . 3

2. Taxonomy of cereal crops. ...............4

3. Cereal landraces: origin and threats. . . . . . . 4

4. Survey of cereal landraces and their effective conservation. . . . . . . . . . . 6

5. Landraces sampling and genebank conservation strategies. . . . . . . . . . . 7 
6. Documentation of genetic resources in germplasm collections. . . . . . . . . . . . . . . .8

6.1. Exchange of germplasm information in global network system. . . . . . . . . . . . . . . . 10

7. Management of cereal landraces in genebanks......11

7.1. Ways forward for accession-level information systems. . . . . . . . . . . . . . 13

8. Advantages of providing data to networks.......13

9. Importance of landrace genetic resources held in genebanks. . . . . . . . . . . . . . . 13

10. Overview of cereal landraces in global information systems....................... .

10.1. Wheat landraces in genebanks. . . . . . . . . . 15

10.2. Barley landraces in genebanks. . . . . . . . . . . 17

10.3. Oat landraces in genebanks. . . . . . . . . . . 19

10.4. Rye landraces in genebanks. ........... 20

11. Conclusions. .....................21

12. Acknowledgements. . . . . . . . . . . . . 23

13. References. . . . . . . . . . . . . . . . . 23

\section{Introduction}

Cereal crops, such as wheat, barley, oat and rye, have historically been the staple foods in Europe and West Asia and are also the principal "founder crops" from which food production was launched in these regions (Zohary and Hopf 2000). Since the beginning of agriculture, farmers have developed different crop traits through the selective sowing and plant harvesting, and by saving selected seeds for subsequent growing seasons. Moreover, the differences in agroecological conditions and agricultural practices between communities have resulted in the development of locally adapted varieties, known as landraces. The first reference to landraces as genetic resources appeared in 1890; the term was later applied to cereals by von Rümker (von Rümker 1908; Zeven 1998). Various terms, including "primitive cultivar", "traditional variety" or even "conservation variety", have served as synonyms, with little consistency in their application and no consensus among experts as to their use in the literature (Camacho Villa et al. 2005). Despite several attempts to define landraces (Berg 2009; Brush 1995; Friis-Hansen and Sthapit 2000; Harlan 1975; IBPGR 1980; Louette 1999; Newton et al. 2010; Tsegaye et al. 1996; Pistorius 1997; Saxena and Singh 2006; Zeven 1998), a satisfactory description based on knowledge of their traits, use, eco-geographic adaptation and cultivation and management procedures is yet to be defined. Nevertheless, it is commonly understood that thousands of landraces reveal a specific variation of morphological and yield characteristics, as well as other desirable traits, including quality traits ( $\mathrm{Li}$ et al.
2009; Moragues et al. 2006; Pecetti et al. 2001; Teklu and Hammer 2009; Tsegaye et al. 1996), agro-ecological adaptations (van Hintum and Ellings 1991), abiotic stresses (Trethowan and Mujeeb-Kazi 2008; Reynolds et al. 2007) and resistance to pests and diseases ( $\mathrm{Li}$ et al. 2009; Saker et al. 2008). These traits have evolved as a result of natural and non-orientated anthropogenic selections, acting individually or in combination, and in close interaction with respective crop wild relatives in the domestication and diversity centres.

Based on general characteristics defining landraces, Camacho Villa et al. (2005) proposed a definition that captures its essence: "A landrace is a dynamic population(s) of a cultivated plant that has historical origin, distinct identity and lacks formal crop improvement, as well as often being genetically diverse, locally adapted and associated with traditional farming systems". However, misunderstandings regarding the correct identification and documentation of landraces prevail in both the literature and in GeneBank record systems. The Camacho Villa definition suggests that a cereal landrace is indeed a complex of geographically related crop populations, in which a dynamic balance of genotypes can be detected both within and among populations. For the great majority of cereal landraces, the structure, size and relationship between key alleles or genetic entities are still unknown (Bellon 1996; Kebebew et al. 2001; Rawashdeh et al. 2007; Teklu and Hammer 2009; Tsegaye et al. 1996; van Hintum and Ellings 1991). Such gaps created the present situation, whereas documentation of germplasm accession or population is majorly equalised to a landrace. A comprehensive knowledge of cereal landrace diversity is essential to define landrace sampling strategies, GeneBank core collections and to ensure an accurate documentation (Aguiriano et al. 2006; Teklu et al. 2005). Knowledge about landrace features may play a vital role in determining the structure and size of germplasm collections, as well as in the definition of accession numbers, regeneration requirements and quality control to avoid genetic erosion and drift. van Treuren and van Hintum (2001) and van Treuren et al. (2005) showed that self-pollinated cereal landraces may consist of several entities or genotypes coexisting in the same landrace population as subpopulations. Parzies et al. (2000) reported that in the initial collections of barley landraces held in GeneBanks, more than half of the total genetic variation could be found within the landraces, while the remainder exists between the landraces. These data coincide with the variation of spike and seed qualitative and quantitative traits in the "Batini" barley landrace, where 40 and $60 \%$ of the total phenotypic diversity was partitioned among and within its subpopulations, respectively (Jaradat et al. 2004). Effective evaluation of the representativeness of the existing cereal collections in relation to the crop diversity is hampered by the absence of early regional or national surveys of crop landraces, which do not allow us to determine indices of their erosion and/or extinction. 
The organisation and role of GeneBanks has changed considerably since they were first established in the early twentieth century. GeneBanks initially aimed to support breeding efforts and the introduction of new varieties, and most of the contemporary germplasm collections still support these traditional objectives. These collections, which include accessions with a narrow genetic base, can preserve important genes required for breeding purposes. However, they are restricted in their ability to meet the needs of other users and have limited capacity to conserve crop biodiversity, where unknown and potentially useful traits may be present. One of the most significant obstacles to enhancing the use of GeneBank materials is lack of adequate prospecting and evaluation data available, as well as the capacity to generate and manage such information (FAO 2010). Difficulty in accessing GeneBank material, due to a reluctance to respond to seed inquiries, is still considered a key GeneBank management issue (Finkel 2009).

The main objective of the present work is to provide a critical review of the available knowledge of wheat, barley, oat and rye landrace resources maintained in GeneBanks worldwide and to analyse available information with regard to these collections and how this information could be more effectively shared to promote sustainable agriculture.

\section{Taxonomy of cereal crops}

Analysis of the bibliographical records, available databases and metadata information reveals that the use of different taxonomic nomenclature systems creates a major problem in the analysis of data for crop cereal collections. At the same time, the taxonomic classification itself is not sufficient to eliminate the duplication or misidentification of the accessions (Dobrovolskaya et al. 2005). The problem is aggravated by the nature of landrace category, given that we are dealing with a resource category below botanical variety rank.

This problem mainly affects wheat, a major world cereal, and its economic significance, and is reflected in the number of existing collections as well as the total number of accessions held in GeneBanks. The number of taxonomic systems used to classify wheat resources, 14 different systems are used by the GeneBank curators worldwide, also reflects this limitation. These nomenclature systems have been successively reviewed by Dorofeev et al. (1979), Gandilyan (1980), Kimber and Sears (1987), Kimber and Feldman (1987), Löve (1984), Mac Key (1988) and van Slageren (1994) and differ by the number of the recognised species, subspecies and botanical varieties. The inability to undisputedly identify botanical varieties within the wheat species (Triticum monoccocum L., Triticum dicoccum Schrank, Triticum durum L., Triticum turgidum L., Triticum aestivum
L. and Triticum compactum L.) creates additional difficulties in accurately classifying wheat landraces. The application of a molecular approach appears to be a promising technology, offering reliable separation of accessions or identification of duplicates, as it correlates well with the classification of botanical varieties (Dobrovolskaya et al. 2005). However, further effort is needed to increase the number of markers specifically correlating with traits distinguish different varieties.

Barley taxonomy is much simpler, with two major taxonomic systems recognised, e.g. the Nevski (1941) system with 28 species, whereas Hordeum vulgare L. and Hordeum spontaneum C. Koch, as well as Hordeum agriocrithon Åberg, are considered separated species, and Bothmer and von Jacobsen (1985) with 40 taxa, whereas three aforementioned species are considered subspecies of $H$. vulgare (NCBI 2012). Classification of varieties is less developed than for wheat taxonomy and is applied only within the same GeneBank. An important number of barley accessions without species identification have been detected.

The Avena taxonomy was a subject of several revisions especially in what concerns the genus boundaries (Baum 1968). Twenty-five species are included in the genus Avena (Loskutov 2003), but only four of them are cultivated, e.g. Avena strigosa Schreb., Avena abyssinica Hoch., Avena byzantina Koch and Avena sativa L. Our GeneBank documentation survey detected an enormous number of accessions without species identification and non-cultivated species with accessions classified as landraces. Landraces are expected to be found in collections of cultivated species, although their classification in botanical varieties is scarce.

Historically, 15 rye species are recognised (Roshevitz 1947; Delipavlov 1962), but recent classifications assemble them into four species Secale cereale L., Secale sylvestre Host, and Secale vavilovii Grossh., including the perennial species Secale strictum (Presl.) Presl. (Sencer and Haekes 1980; de Bustos and Jouve 2002) and 13 subspecies, whereas $S$. cereale subsp. cereale is cultivated rye. However, all the classifications can be found in the documentation of crop germplasm collections. The survey shows lower number of accessions without species or non-cultivated species with accessions classified as landraces.

However, in the present work we used the Brummitt and Powell (1992) taxonomic classifications for barley, oat and rye crops.

\section{Cereal landraces: origins and threats}

Cereal landraces emerged in different regions of the world as a result of centuries of crop evolution in traditional agrosystems. Throughout the centuries, farmers have been the keepers of cereal diversity (Jones et al. 2008), saving the 
seeds from harvests for the next generation and increasing gene flow through seed exchanges with relatives and neighbours or through the introduction of local or exotic materials. These practices show the importance of farmer communities and traditional farming systems in the development and maintenance of the landraces (Zeven 2002). The farmers have also maintained traditional knowledge on cereal landraces uses, playing a critical role in their documentation. Since the 1950s, landraces have been increasingly replaced by modern varieties, which offer superior yields but are less adapted to changing environmental conditions and therefore require higher inputs of fertilisers, pesticides and irrigation to exhibit full yield potential. The introduction of these genetically uniform cultivars, as well as the ageing of rural population and mass exodus of young workforces from rural areas, has resulted in the subsequent abandonment of traditional agricultural practices. These high input, low labour intensive monoculture systems pose serious threats to landrace diversity (Guarino et al. 1991; Negri 2003). Moreover, the advent of modern agriculture, associated with globalisation and environmental degradation, has polluted, eroded and, in many cases, contributed to the loss of cereal landraces. Consequently, unique cereal diversity has been irreversibly lost and information regarding many traditional varieties is now fairly scarce. It is estimated that $75 \%$ of crop genetic diversity has been lost only within the last century (FAO 1998). Not surprisingly, landraces are currently one of the most threatened components of plant diversity in many world countries. The situation is further aggravated by the absence of landrace inventories, decreasing landrace cultivation and, more generally, the absence of national institutions responsible for their conservation. Observing these trends, Zeven (1998) concluded that landraces will eventually vanish and be entirely replaced by exotic and improved cultivars. The analysis of 104 country reports clearly shows that genetic erosion in cereals is more severe than in other crops (FAO 2010). Genetic erosion in cereals and grasses was identified as a problem in 30 countries. It should be noted, however, that these data may reflect the high attention generally paid to field crops (FAO 2010).

In spite of this trend, cereal landraces are still cultivated on marginal land, as their adaptability to unfavourable conditions represents an advantage and contributes to yield stability (Tesemma et al. 1998), tolerance to abiotic stresses (dos Santos et al. 2005; Newton et al. 2010; Pinheiro de Carvalho et al. 2003) and resistance to pests and diseases (Bellon 1996). The significance of cereal landrace diversity in germplasm collections has been assessed by Jaradat et al. (2004) and Parzies et al. (2000). Unless appropriate actions are taken, the trend in erosion is expected to continue or even intensify. There is general agreement that landraces constitute a key genetic resource to support food security and quality, to deal with future climatic changes, or to satisfy shifting consumer needs and demands (del Greco et al. 2007), so this trend in erosion must be halted or reversed.

Genetic erosion, one of the major factors contributing to the decrease of cereal diversity, can be defined as "the permanent reduction in richness or evenness of common localised alleles or the loss of combination of alleles over time in a defined area" (Guarino 2003). This definition takes into consideration both components of diversity: the number of different entities and their relative frequencies, suggesting that the loss of locally adapted alleles is a key event. Genetic erosion is caused by several factors such as anthropogenic and/or natural changes, including replacement of local varieties, land clearing, over exploitation, population pressures, environmental degradation, changing agricultural systems, over grazing, pests and diseases, weeds and inappropriate legislation and policies (FAO 2010). Several attempts have been made to evaluate genetic erosion among cereal landraces (Martos et al. 2005; Rocha et al. 2008; Ruiz et al. 2002). Unfortunately, numerous gaps in the knowledge regarding the origin and structure of cereal landraces only allow us to theoretically anticipate the extent of their genetic erosion. Monitoring genetic erosion in landraces is scientifically, technically and logistically difficult, and requires long-term commitment and substantial efforts of different institutes. Standard and easily applied methodologies are required to provide credible estimations of the status and dynamics of landraces and to permit the analysis of specific target traits, their genes and alleles (Diulgheroff 2006). Additionally, a multidisciplinary approach needs to be developed to perform an integrated analysis of different sources of information.

A second threat faced by cereal landraces is genetic pollution, i.e. the initial diversity of crop landraces is contaminated by "the gene flow from conventional and biotechnologically bred crops and introduced exotic and alien species" (Altieri 2003; Bettencourt et al. 2008; Ellstrand 2001). Genetic pollution is a growing risk and concern, as it represents a threat to the in situ (in genetic reserves and on-farm) conservation of crop landraces and ultimately affects the environment and human health (Bettencourt et al. 2008).

The loss of diversity of cereal landraces as a consequence of their reduced number, size, and increasing pollution, erosion or disappearance, severely threatens the world's long-term food security. The reduction (erosion) and contamination (pollution) of crop diversity by any cause or means has a "domino effect" and thus affects agriculture, which is, to a great extent, dependent on a few crop species and selected cultivars (Bettencourt et al. 2008), whereas cereal crops occupy top positions in food supply. Previous efforts have been made to address the issue related to the comprehensive inventorying the cereal genetic resources 
held in GeneBanks (Bettencourt and Konopka 1990). However, major limitations in determining the number, origin and structure of landraces arise from the scarcity of national inventories of landraces, which hinders adequate sampling efforts and the need to properly identify the landraces in order to evaluate their diversity and conservation status. International research commitments need to be made to address these issues, as well as through the development of standardised methodologies for screening of landrace diversity and evaluation of their conservation status. The use of historical records in herbaria, field mission reports and GeneBank documentation, and the use of GIS techniques with georeferencing of sampled accessions, could improve our knowledge on landraces origin, structure and threats.

\section{Survey of cereal landraces and their effective conservation}

The pioneer of the systematic survey of cereal crop resources was Nicolai I. Vavilov (Damania 2008; Harris 1990). Beginning in the 1920s, Vavilov carried out more than 100 expeditions across the globe, collecting plant materials for the foundation of the N.I. Vavilov Research Institute of Plant Industry (VIR), a central institution responsible for collecting and researching world plant diversity for the purposes of former Soviet Union national breeding programmes. In other countries, similar but smaller scale undertakings aimed at surveying and collecting germplasm of major food and fodder crops, including cereals (Damania 2008), initiating the process of accession gathering that ultimately resulted in a large number of accessions being maintained in GeneBanks around the world (Bettencourt and Konopka 1990; FAO 1998, 2010; Knüpffer 2009; Zeven 1998). Although the concept of a landrace was developed more than 120 years ago, almost all systematic programmes of germplasm prospecting began during the 2nd half of the last century. The use of GeneBank documentation data through the advent of global systems of information exchange has remarkably expanded the possibility of performing landrace inventories at national, regional or global levels. A recent example includes a regional survey on the status of on-farm conservation, management and use of the European landraces (Veteläinen et al. 2009). This document provides an overview of landrace inventories in Europe, their management and use promotion, as well as the development of the European legal framework supporting landraces conservation and use in the context of sustainable agriculture. In recent years, relatively few comprehensive inventories presenting cereal landraces have been published. These include the morphological description of the Portuguese and Madeiran wheat landraces and old cultivars (dos Santos et al. 2009; Vasconcelos 1933); the field survey of wheat landraces from the Panjsher valley (Buerkert et al. 2006) and the Austrian Alps (Zeven and Schachl 1989); and wheat and rye landraces from Ethiopia (Assefa and Labuschange 2004; Bechere et al. 1996).

The absence of detailed cereal landrace inventories from the beginning of the twentieth century, as well as limitations in accessing "grey literature" (unofficial reports of surveys and collecting missions), do not allow for reliable estimations of erosion and extinction rates that have taken place during the past four decades. Despite this gap, there is some information available. Papadakis (1929) provided detailed morphological descriptions with reference to botanical variety and information on the agronomic performance and cultivation area of several Greek wheat landraces cultivated during that period. Very few of these can still be found sporadically cultivated for personal consumption, while several have survived conserved ex situ in GeneBanks around the world. Damania (2008) mentioned that 97 \% of Greece's durum wheat landraces were replaced by improved cultivars of predominantly Italian origin. In a pioneered work, published almost 80 years ago, Vasconcelos (1933) identified 116 Portuguese wheat landraces and provided detailed information, including photographs and morphological descriptions for 95 of them. Out of all the wheat landraces described, only four morphological variants of 'Barbela' could now be found as seed mixtures in northeast Portugal where this type of wheat is still cultivated for production of valuable flour used in making traditional breads and biscuits (Ribeiro-Carvalho et al. 2001). Rocha et al. (2008) also found further evidence of the occurrence of wheat genetic erosion in northwest Portugal caused by a successive abandonment of traditional varieties and increasing use of commercial, improved varieties. This, in turn, contributed to the disappearance of traditional agro-systems, crop landraces and the traditional knowledge associated with their maintenance, management and use in Portugal.

The Second Report on the State of the World's Plant Genetic Resources for Food and Agriculture (FAO 2010) provided several examples of genetic erosion, as cited in various country reports. However, since such information was not standardised, cross-country or cross-crop comparisons cannot be made and information cannot be used as a baseline for further monitoring of their conservation. Nevertheless, the examples presented in the report undeniably highlight the enormous wealth of genetic diversity that is being lost, in some cases, at alarming rates. Yemen reports that cultivation of wheat landraces, including $T$. dicoccum, has drastically decreased. In Albania, all primitive wheat cultivars have been reportedly lost.

Undertaking a credible evaluation of the current status of the cereal landraces conservation is complicated, as the FAO country reports only provide a fragment of the global picture 
that can be obtained solely through global information systems. While recent studies have confirmed that diversity in farmers' fields and in protected areas has indeed decreased, this trend in genetic erosion can neither be generalised and nor widely applied as there are cases in which no credible evidence of genetic erosion could be confirmed (FAO 2010). Such discrepancies in the assessment of extinction and erosion rates of landraces needs to be clarified through careful review and cross-referencing of data originating from different sources, including field mission reports, herbaria collections, natural history museums and GeneBank data. Unfortunately, only a very limited number of initiatives focused on resolving these discrepancies are currently underway. The EU project "AEGRO, AGRI GENRES 0572006-0396" aimed to establish a database platform combining data from various sources, to identify adequate place for in situ and on farm conservation of oat landraces and related CWRs as well as other crop landraces and to promote the guidelines for their in situ conservation (Maxted et al. 2012). Project implementation detected a pressing need to create up-to-date inventories of cereal landraces at the national and regional levels, including the geo-referencing of presently cultivated landraces. This urgency is also due to the importance of cereal landraces for low input and organic farming, breeding and development of traditional products with protected denomination of origin. Accordingly, the Commission Directive 2008/62/EC of 20 June 2008 came into force to promote a wider utilisation of genetic diversity in agricultural systems and to improve the management of plant genetic resources through the recognition of agricultural landraces and varieties to be grown and marketed (EC 2008).

The elaboration of cereal landrace inventories is most certainly conditioned by different interpretations or understandings of the definition of a landrace (Camacho Villa et al. 2005; Zeven 1998) and the existence of specific regional (EC 2008) and national regulations aimed at their protection (DGADR 2009; Lorenzetti et al. 2009; Lorenzetti and Negri 2009; MADRP 2009). Further efforts on standardising the definition of a landrace, initiated by Zeven (1998) are therefore required. Among the European countries, Italy appears to be the most advanced in terms of creating national landrace inventories (Lorenzetti et al. 2009; Negri 2003; Porfiri et al. 2009; Torricelli et al. 2009).

\section{Landraces sampling and GeneBank conservation strategies}

Initially, GeneBanks were established to conserve collected plant material to support breeding programmes. Only after 1974, when heavy erosion of genetic resources was recognised as a serious problem, did the function of GeneBanks evolve to include conservation of crop genetic resources and, in some cases, of their crop wild relatives (Damania 2008). This broadening of GeneBank mandate dictated the need for subsequent changes in sampling strategies and additional requirements for thorough documentation of the collected accessions. Modern GeneBanks have diversified research tasks that encompass plant genetic resources surveys, collection, conservation, characterisation, documentation, valorisation and promotion of germplasm use. In this review, the tasks directly related to sampling and conservation of cereal landraces is discussed. Usually, accessions conserved in GeneBank collections result from direct sampling of farmers' fields, farm seed stores or even local seed markets (Damania 2008) with one accession representing a specific crop population. Some authors (Zeven 1998; Negri 2003) consider an accession to be a crop landrace if it has been locally cultivated by farmers for several decades or generations in the absence of formal or conventional selection. Others consider accessions to be populations belonging to a particular landrace, if they share common key traits and have a history of traditional use (Camacho Villa et al. 2005; dos Santos et al. 2009). The first approach allows the classification of an accession as a landrace in the absence of its characterisation, using, for example, the provenance and common name information for the classification. The second approach, however, requires previous characterisation of landraces and the determination of their genetic structure and sample sizes for proper conservation of their diversity. According to Dobrovolskaya et al. (2005), the use of the common or cultivar name is not sufficient to determine the presence of duplicates and to downsize germplasm collections, because of existence of genetically different accessions under the same common designation. Demissie and Bjornstad (1996) proposed the use of phenotypic variation of some traits as a methodology to sample and conserve barley landraces.

Plant accessions of locally grown cereals have complex structures, are characterised by their plasticity, are adapted to local agro-ecological conditions and their diversity can be increased by farmers' seed exchange (Zeven 1998; Ladizinsky 1998; Bellon 1996; Damania 2008; Newton et al. 2010). Due to the diversity and heterogeneity of landraces, germplasm sampling requires specific and extensive care, during both the gathering (Allard 1970; Brown and Marshall 1995; Hawkes et al. 2000; Farias and Bettencourt 2006) and regeneration of landraces, in order to maintain rare alleles and genotypes and to avoid genetic drift. Germplasm sampling techniques have been the subject of numerous recommendations. While Allard (1970) and Bennett (1970) recommend the sampling of 200 to 300 plants, Qualset (1975) recommends 500 plants for wild populations of cereals, and Yonezawa (1985) proposes the sampling of ten plants per site, stressing, however, that the 
number of collecting sites should be high. This is also supported by Porceddu and Damania (1992), Damania (1996) and Hawkes et al. (2000). A compilation of works on this topic was presented by Guarino et al. (1995). The sampling methodology employed during collecting missions, as well as the practice of regenerating samples through multiplication, may lead to genetic changes and loss of sample alleles, ultimately resulting in genetic erosion of the landraces (Parzies et al. 2000; Mantzavinou et al. 2005). However, the deficiencies occasionally identified in sampling strategies have contributed to the problem of genetic drift in accessions, which is sometimes aggravated by incomplete and scarce information about the collected sample. The International Plant Genetic Resources Institute (IPGRI; now Bioversity International) developed specific recommendations and standardised methodologies for germplasm sampling and collection (Hanson 1985; Hammer et al. 1999; Rao et al. 2006) and recommends the collection and use of at least 4,000 seeds to conserve the diversity of heterogeneous material (Rao et al. 2006).

The use of a large number of seeds per sample, and their regeneration before viability drops below $85 \%$, are considered critical to prevent the loss of rare alleles and avoid genetic drift. However, these sampling requirements and the size of germplasm accessions seem to be crop- or landracespecific (Hirano et al. 2008, 2009). The size and frequency of sample collections for storage and ex situ conservation, as a complementary strategy to in situ and on-farm conservation programmes has also been discussed. Brown and Marshall (1995) studied sampling requirements pertinent for collection of genetic diversity and for determining the sample size for ex situ conservation. The authors found that the analysis of a minimum of 50 randomly sampled individuals per population is required in order to achieve $95 \%$ probability that at least one copy of each allele occurring in the population with $5 \%$ frequency is detected. However, this sample size does not permit conservation of all allele combinations present in a population or a landrace. Even though sampling strategies have been developed to ensure that the 'within' landrace diversity is collected before the accession is stored in a GeneBank, less attention has been given to the maintenance of this diversity during GeneBank storage (Parzies et al. 2000; Sackville Hamilton and Chorlton 1997) which can also compromise the future utilisation of the landraces. Thus, genetic erosion occurring in GeneBanks is now a growing concern and it has become evident that the research and management of biodiversity requires new approaches (Hammer and Gladis 1996; Hammer and Spahillar 1998). Recent guidelines for GeneBank management, proposed by the IPGRI, in collaboration with the FAO, the CGN (The Netherlands), the Government of The Netherlands and the System-wide Genetic Resources Programme (SGRP) (Engels and Visser
2003), emphasise the importance of standardised management procedures, sampling strategies, conservation, viability monitoring and regeneration methods aiming to maintain the accession integrity and documentation management. . The evaluation of cereal landraces diversity and the status of germplasm collections, including the integrity of accessions, their conservation and viability are barely present in the scientific literature. The Spanish collection of durum wheat was evaluated in relation to the accession origin and source of agronomic and resistance traits (Ruiz and Martín 1998), as well as viability (Ruiz et al. 1999) and the presence of duplicates in the collection (Ruiz and Aguiriano 2004). Using the gliadin pattern as a marker, the authors confirmed the presence of 106 instances of duplication among 266 accessions of durum wheat collections. Several other authors also provided evidence of genetic information loss during conservation and regeneration (Wood and Lenne 1997; van Hintum et al. 2002; Chebotar et al. 2003). On the other hand, some researchers argue that the diversity of accessions does not change and genetic drift does not occur during ex situ conservation (Rice et al. 2006). The use of fast molecular and biochemical screening tools is recommended for monitoring accession diversity and for the management of the enormous amount of genetic resources deposited in the GeneBanks. A reliable estimation of landrace diversity will ensure against genetic drift and loss of genetic information during the management of the germplasm collections. The minimisation of genetic erosion and its negative impacts on sustainable agriculture through the monitoring of key elements of genetic resource conservation will be further facilitated by the analysis and exchange of the available information. To that end, as proposed in the Second Global Plan of Action for Plant Genetic Resources for Food and Agriculture (FAO 2011), governments should periodically review and report on the situation of PGRFA, designating a focal point to convey this information to FAO, and, as appropriate, to the Governing Body of the International Treaty, the Conference of the Parties to the Convention on Biological Diversity (CBD) and other relevant bodies, endeavouring special efforts to identify the species and populations that are most at risk and are most likely to harbour traits that will be important in the future; this is particularly important with regard to landraces and CWR.

\section{Documentation of genetic resources in germplasm collections}

Scarcity of information about landrace characteristics is a major issue faced by the GeneBank users. In spite of that, many landraces can be identified by morphological or agronomic traits and their description is sufficient for a proper 
selection of plant material; herbaria vouchers can assist in this respect. The unmistakable identification of a germplasm sample is a prerequisite for the application of an appropriate conservation strategy and the promotion of its sustainable utilisation. Accessions, which cannot be identified due to the absence of a herbarium specimen, tend not to be utilised for longer periods of time than those which have been assigned verified names (Moss and Guarino 1995). This specifically applies to the landraces of some minor cereal species, with contradictory taxonomy, which play an important role in overall crop diversity. It is believed that the first herbarium was established in 1570 in Bologna, Italy, by Luca Ghini. The Index Herbariorum (2012), a Global Directory of Public Herbaria and Associated Staff, refers the existence of approximately 3,400 herbaria with approximately 10,000 associated curators and biodiversity specialists. These herbaria, collectively, maintain an estimated 350 million specimens. To understand the magnitude of the collections maintained by an individual herbarium, consider that the nine largest herbaria in the world maintain a total of 55.3 million specimens. Unfortunately, major herbaria collections are not linked to GeneBanks and, therefore, the amount of voucher specimens related to cereal crops or their landraces remains unknown. Ideally, herbarium specimens ought to be collected for all new germplasm accessions and specifically for the landraces, rare or unusual types, minor crops and CWR. Such a system would assist in clarifying any doubts arising over an accurate identification of a plant species (Moss and Guarino 1995).

Herbaria are a valuable source of information for GeneBank curators and users, assisting in the planning of germplasm collecting missions, as a reference source for the identification of new entries and material, and studies on crop distribution. Herbaria are also important for documenting existing germplasm collections providing the identification of sources of material, since accessions of CWR are often accompanied by herbarium voucher specimens collected either in the field or during any subsequent regeneration activities (Perry and Bettencourt 1995; Bettencourt 2011). In addition, due to advances in biotechnological sciences, it is also possible to extract DNA from herbarium vouchers for genetic diversity studies (Liston et al. 1990; Jones et al. 2008; Leino and Hagenblad 2010). If properly collected, prepared and stored, a voucher is bound to the sample location and the specific accession will indefinitely be available for study by future generations (Miller and Nyberg 1995). As such, herbaria specimens play an important and complementary role in the assessment of resources distribution, erosion and extinction. Damania (2008) presented several examples of the role of herbaria and germplasm documentation with regard to the assessment and recollection of resources. Herbaria can also help to control sample integrity against genetic drift and erosion occurring in the GeneBanks, as the accessions often undergo numerous regeneration or multiplication cycles, or are grown or regenerated under different climatic and soil conditions, which may produce substantial, mostly phenotypical changes, from the original population. In such cases, herbaria serve as a useful record of the original samples (Miller and Nyberg 1995).

Finally, herbarium documentation is also important to: follow the location of plants that have potential to be used as new crops; document the plants used as crops and forage; locate and identify cereals' CWR for use in breeding programmes; identify crop landraces in a specific area in order to define the habitat and designate an environmentally and legally appropriate use for the site; and establish landrace inventories.

However, both the herbarium specimens and GeneBank samples are of limited value if they are not combined or coupled with other documentation data. These data show some similarities between the herbarium (where the information is recorded in label notes) and the GeneBank (where passport data are used) documentation systems. Much of the data needed to document a voucher should be also provided by the accession's passport, including the name(s) of the collector(s) and institute, collection number, collection date and the collection site. Additionally, taxonomic identification, notes and drawings should be made to record any of the plant's characteristics which might be lost or less evident in a dried specimen (Miller and Nyberg 1995).

The documentation of germplasm accessions is another important issue in the facilitation of sustainable use of genetic resources. Most GeneBanks actually have developed their own documentation systems based on the IPGRI recommendations (Painting et al. 1993). The passport data, a fundamental part of this documentation system, are linked to germplasm accessions to facilitate the identification of plant material needed for breeding or conservation purposes. These passport data include all information present in the vouchers' labels, as well as the accession numbers, donors' name, geographical and habitat data and agricultural system information. These data are often accessible to the general public through GeneBank databases. However, the accession passports lack information related to the plant taxonomy or data needed to identify a landrace's status and to characterise specific traits. In the past, plant genetic resources were also documented by the missions and expedition reports and catalogues published after collection and/ or evaluation of germplasm (Agrawal et al. 2007). Based on a case study of the United States National Plant Germplasm System (US NPGS), Smale and Day-Rubenstein (2002) found that inadequate or incomplete information about accessions is cited by $38 \%$ of users as the major problem affecting the utilisation of germplasm. Improved documentation of genetic resources is an imperative for planning and 
implementing targeted and appropriate strategies for conservation, sustainable use and benefit-sharing. Concerning cereal landraces and their wild relatives, an effort must be made to better characterise and evaluate these resources in order to achieve a more in-depth understanding of species diversity, which will allow for enhanced identification of germplasm and traits, and their advantages for agriculture and food. This could be accomplished by carrying out improved ethno-botanic studies, which include detailed information about farming systems and agricultural practices, eco-geographic adaptation, pest resistance and tolerances, abiotic resistances and trait preferences, i.e. all knowledge available about the collected sample. This approach would prevent information gaps, such as those that hamper the sustainable utilisation of genebank materials by farmers and plant breeders. In ex situ collections, the following information enables the accurate identification of accessions: accession number and taxonomic name; place of collection and where the material originated; description of morphological and agronomic traits; viability test results; regeneration data; location(s) where material has been distributed; to whom has the material been donated; related ethno-botanical information; and farmer and indigenous knowledge.

The collation, exchange and provision of this useful accession-level information are easily justified through the existing conventions and treaties. Sharing of such information is fundamentally aimed at facilitating better management and increased access to and utilisation of cereal landraces genetic resources by a large community of stakeholders (e.g. GeneBank curators, researchers, breeders, farmers and students). The access to comprehensive information on ex situ holdings would enable GeneBank curators, as well as other users to: identify new sources of diversity in other collections; assess possible gaps in their collections; plan additional collecting missions; identify duplicates of existing material; secure proper and safety duplication and regeneration of accessions; promote utilisation of germplasm by identification of useful traits for breeders or adapted to different climates; contribute to development of appropriate conservation strategies; and support complementary conservation via ex situ/in situ and on-farm methods to enhance food security and quality.

6.1 Exchange of germplasm information in a global network system

Proper management and availability of data are essential to promote the use of crop diversity for research, breeding and training. While improved data quantity and quality has been recently noted (FAO 2010), a unified system of record maintenance and universal information accessibility would promote the wider use of the collected landraces.
Great progress made in this field during the last decade may be attributed to the use of modern information technologies. The recent institutional, regional and global initiatives have focused on compiling and standardising information to facilitate the accessibility of data that have been frequently inaccessible during the pre-computer era. The global exchange of information has expanded remarkably since the inception of the internet. Technological advances have enabled the distribution of electronically available data from major centres to remote parts of the world.

Current challenges in the global exchange of germplasm information range from the interoperability of large data sets and addressing the needs of data providers, to creating customised data analysis tools for end-users, in order to ensure their quality. The importance of web-based portals and online databases and platforms for the conservation and use promotion of agrobiodiversity is emphasised by both the data providers and the users. Given the recent and rapid changes in information technology, the development of national and regional portals and a global information system on plant genetic resources for the GeneBank community is both practical and logical. Existing GeneBank information systems and portals, such as the European Plant Genetic Resources Search Catalogue (EURISCO 2012), the CGIAR System-wide Information Network for Genetic Resources (SINGER 2012) and the Germplasm Resources Information Network (GRIN) of United States Department of Agriculture (USDA) are the essential building blocks for creating a global framework on access to genetic resources. Construction of such a large-scale information infrastructure requires thorough consideration and careful selection of the strategy, methodology and technology to be employed (Gaiji et al. 2008).

In recent years, a transition from individual GeneBank website access to multi-institutional portals has occurred. An example of this is the EURISCO Catalogue (http://eurisco.ecpgr. org).which provides a European entry point on passport information for more than one million accessions, representing approximately $50 \%$ of the total number of accessions conserved in Europe, in 318 GeneBanks from 42 countries. Another is SINGER (http://www.singer.cgiar.org - to be incorporated into GENESYS) provides a central point of access to all germplasm conserved in the 11 CGIAR GeneBanks, containing data on more than 700,000 accessions. Finally, the GRIN (http:// www.ars-grin.gov/npgs.html) provides easy access to information on more than 510,000 accessions. Nonetheless, accessing GeneBank information in many countries is still a complex task, mainly due to inadequate documentation systems at the individual GeneBank level, coupled with a low level of coordination at the national and regional levels. To address the documentation system issues at the individual GeneBank level, a partnership involving the Global Crop Diversity Trust, USDA and Bioversity International, developed and deployed a GeneBank 
documentation system called GRIN-Global, based on a system in use by USDA. Its goal is to provide the world's crop GeneBanks with a powerful, flexible, easyto-use global plant genetic resource information management system that will constitute the keystone for an efficient and effective global network of GeneBanks to permanently safeguard plant genetic resources vital to global food security, and to encourage the use of these resources by researchers, breeders, and farmer-producers. By improving the capability of GeneBanks in feeding their data into a global accession-level information system, under the leadership of Bioversity International, it will be possible to more accurately assess the "State of the World" with regard to plant genetic resources, and to identify priority global needs for their conservation (http://www.grin-global.org/index.php/Main_Page).

In order to ensure continued and diligent conservation of cereal landraces, world GeneBanks should implement measures to standardise procedures, establish compatible documentation systems and develop frameworks aimed at a better management and exchange of genetic resources information. Within Europe, the European Cooperative Programme for Plant Genetic Resources (ECPGR) and the South-East European Development Network on Plant Genetic Resources (SEEDNet) are key examples of networks established to improve germplasm management and information exchange. Both programmes illustrate successful collaborations through networks with targeted research agendas and combined structural support. The fundamental operating principle of the existing information systems is that they are based on free and open access to the biodiversity data. Currently, data providers in the EURISCO, SINGER and GRIN networks offer free information about their accessions in collection.

On a global scale, a portal that facilitates access to and use of information, as a single entry point for users wanting to mine genetic variation by searching for combinations of data on the characteristics, environments and other aspects of genetic diversity, has been developed, called GENESYS (Dias et al. 2011). GENESYS was created to improve access by the breeders and other plant scientists to the germplasm they need in a format that is easy to understand by allowing them to identify accessions of interest and order them online directly from the GeneBanks holding that specific material. GENESYS specifically addresses the challenge of making information about germplasm collections readily available for the general public, as a key factor contributing to increasing the use of plant genetic resources for food and agriculture (PGRFA).

The foundation data for the GENESYS global portal (Fig. 1) is the information provided by three major international project partners: the European Cooperative Programme for Plant Genetic Resources (ECPGR-EURISCO), the System- wide Genetic Resources Programme (SGRP-SINGER) of the Consultative Group on International Agricultural Research (CGIAR) and the USDA Agricultural Research Service National Genetic Resources Program. Together these systems account for approximately 2.4 million accessions held in ex situ collections worldwide, about a one third of the total number of accessions estimated to be maintained in the GeneBanks globally (Dias and Mackay, Bioversity International, Rome, Italy, unpublished) (www.genesys-pgr.org).

Information-sharing agreements are core to and underpin the use of large GeneBank network information portals such as the EURISCO or SINGER. The agreements clearly define obligations and responsibilities of data providers and the central aggregation point or the institutions assuming that role. The goals and principles of making biodiversity data openly and universally available are defined by the networks' or portals' Memorandum of Understanding (MoU) or Data Sharing Agreement (DSA). Participants who sign these MoUs or DSAs express their willingness to make biodiversity data available through their nodes to foster international scientific research and to support the public use of such data.

\section{Management of cereal landraces in GeneBanks}

A fundamental issue in the management of GeneBanks relates to the information describing each accession and its accessibility. Standardisation of such information is a key element that determines the potential benefits of genetic resources for both seed conservation and breeding purposes. Considering that many of the world's plant genetic resources are insufficiently documented, which prevents optimal access to and compromises the proper use and conservation of these resources, the Global Plan of Action (GPA) for the conservation and sustainable utilisation of plant genetic resources for food and agriculture (FAO 1996, 2011) has recommended the creation of comprehensive information systems for the PGRFA, as well as the development of monitoring and early warning systems for the loss of the PGRFA. These information systems aim to facilitate access to and sustainable utilisation of PGRFA through the collation and exchange of useful information, which also applies to the cereals landraces. The need for such information systems has been determined by the fast growth rate of worldwide GeneBank systems and the challenges of managing the growing amount of genetic resources maintained in these germplasm collections. Information systems have been developed at several levels, including national (national plant germplasm networks), regional and international (documentation at meta or accession levels). In this section, the selected systems developed at the national level will be 


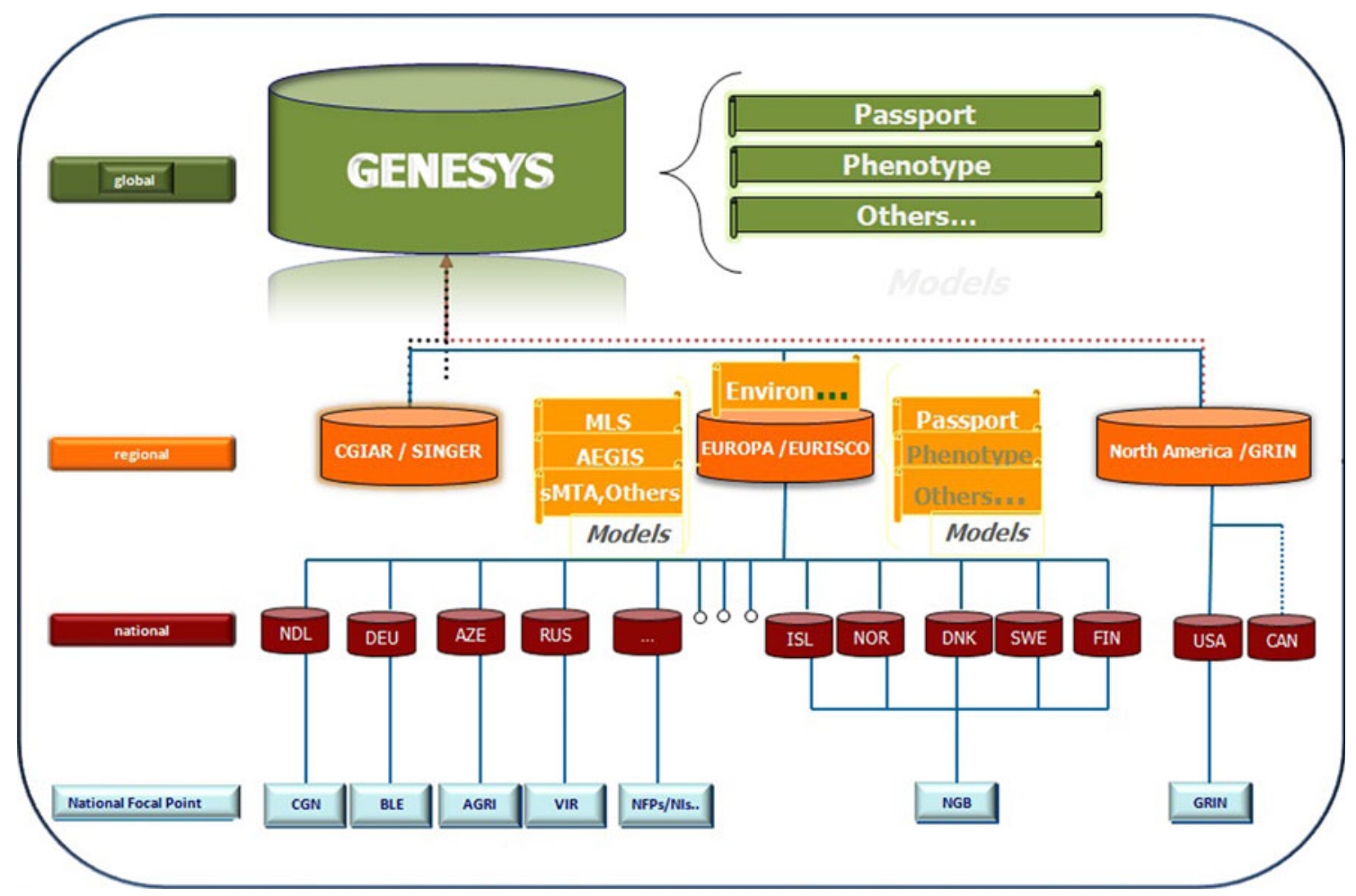

Fig. 1 Global system backbone levels and data providers' schema. CGIAR Consultative Group on International Agricultural Research, SINGER System-wide Information Network for Genetic Resources, EURISCO European Plant Genetic Resources Search Catalogue, GRIN Germplasm Resources Information Network, CGN Centre for Genetic Resources, the Netherlands, $B L E$ Federal Agency for Agriculture and

reviewed and the management of resources held in the GeneBanks will be analysed.

At the crop level, the European information systems have been developed and maintained under the framework of the European Central Crop Databases (ECPGR). Specific information regarding the cereal crops is available from the European Barley Database, the Database on Barley Genes and Genetic Stocks, the European Wheat Database, the Internet Catalogue of Wheat Pedigree and the European Avena Database (EADB). At the international level, the following systems provide information on cereal crops: the International Barley Core Collection (IBCC); the International Maize and Wheat Improvement Centre (CIMMYT) for wheat; the International Centre for Agricultural Research in the Dry Areas (ICARDA) for cereals; and the International Crop Information System (ICIS) that maintains data on wheat and barley (http://www.cropinfo.org/ icisweb/community.htm, 2012).

It is recognised that with the establishment of VIR in 1924 , the creation of the worldwide system of GeneBanks officially commenced (Loskutov 1999). In 1972, the CGIAR recommended the establishment of a global network for the conservation of crop genetic resources (Frankel and Hawkes 1975). In 1975, the International
Food, AGRI Azerbaijan Genetic Resources Institute, VIR N.I. Vaviloy Research Institute of Plant Industry, NFPS National Focal Points, $N G B$ NordGen (formerly Nordic GeneBank), MLS Multilateral System, AEGIS A European GeneBank Integrated System, SMTA Standard Material Transfer Agreement

Board for Plant Genetic Resources (IBPGR; subsequently IPGRI, presently Bioversity International) reported the existence of eight global genetic resources conservation centres located in developed countries. Today, the number of GeneBanks worldwide exceeds 1,750 (FAO 2010) and the majority is managed according to the IBPGR recommendations.

The extent of utilisation of cereal genetic resources in breeding programmes, research or conservation is directly related to the quality of GeneBanks' documentation and the accessibility of the GeneBanks' data (Smale and DayRubenstein 2002). Agrawal et al. (2007) described the features of the Indian GBIMS based on Microsoft SQL, which manages information on about 320,000 accessions conserved in the GeneBank of National Bureau of Plant Genetic Resources of India (NBPGR), held in nearly 60 different institutions. The US NPGS relies upon the GRIN, which effectively manages the world's largest germplasm collection belonging to the USDA and holds more than 510,000 accessions of the 85 most commonly grown crops, including wheat and barley. In Europe, Germany's Federal Information System on Genetic Resources (BIG) was jointly developed by four partner institutions with extensive databases on wild and cultivated plants. Due to its relevance, it is 
also worth mentioning the Nordic Genetic Resources Centre (NordGen), a common GeneBank, and the respective documentation and information system for the Nordic countries (Denmark, Finland, Iceland, Norway, Sweden) making available information on 24,354 accessions belonging to 730 Genera (NordGen 2012). However, such documentation strategies and systems have not always been implemented at the national level elsewhere. For example, in Portugal, the genetic resources policies are coordinated by the National Institute for Agrarian and Veterinarian Research, yet the information systems of different GeneBanks or institutions working on plant genetic resources are not linked through a network; this situation prevails in many other countries. These documentation systems allow the users to authenticate information on the origin, management and proper maintenance of germplasm accessions. They also reduce the amount of duplications and contradictory records resulting from the misidentification of accessions. However, most importantly, they provide access to the information on genetic resources in real time, allowing for appropriate research planning and promoting the use of genetic resources.

Is it worth mentioning the mechanism for registration of GeneBanks worldwide, which is currently in place through the FAO World Information and Early Warning System (WIEWS 2012; http://apps3.fao.org/wiews/wiews.jsp). This system maintains metadata on germplasm holdings and contains an inventory or catalogue of the world's GeneBanks, the species they conserve and an estimated number of accessions held for each species. Each GeneBank is uniquely identified through an Institute Code (IC), which is widely used within existing GeneBank information systems. For example, information provided by the national inventory focal points to the EURISCO Catalogue should be compliant with the WIEWS Institute Codes. Such metadata is extremely important for the registration and unique identification of potential data providers.

\subsection{Ways forward for accession-level information systems}

Given the level of experience acquired in implementing EURISCO, its methodology and infrastructure should be considered for possible adoption/replication in other regions. EURISCO is an effective and sustainable model that not only addresses the information-sharing aspects of accession information systems, but also the range of completeness and accuracy of data, so as to provide GeneBanks with appropriate tools and sufficient technical and financial support to upgrade their GeneBank information management systems.

\section{Advantages of providing data to networks}

Linking the networks as data providers to the global information system through regional catalogues and national inventories automatically enables the participating countries to uphold/implement their biodiversity and conservation obligations at the national level and to meet the requirements of international agreements such as the CBD, the GPA, the International Treaty on PGRFA and the GBIF. Through the networks, countries are able to use fewer resources while providing more efficient reporting on their PGRFA and the associated information.

It is expected that the global, regional and national information systems will greatly support national and regional strategies for the sustainable conservation and use of genetic resources, in addition to contributing to the well-being of present and future generations and to alleviating poverty while ensuring food security and quality.

\section{Importance of landrace genetic resources held in GeneBanks}

There is a common understanding that ex situ germplasm collections have limited use and primarily serve only for conservation purposes. However, despite the recent changes in the functions of GeneBanks highlighted in the case study of the US NPGS, Smale and Day-Rubenstein (2002) reported that requests for cereal landraces depend on the country, crop, culture and profile of the final users, while breeders are still the main users of germplasm. Globally, plant germplasm, including cereal landraces, is requested for trait evaluation, breeding or pre-breeding, basic research and the enhancement of other collections (Day-Rubenstein et al. 2006; Hajjar and Hodgkin 2007). Only the latter two are related to conservation GeneBank functions. Often, there is an urgent need to preserve neglected landrace resources in order to prevent their disappearance (Hammer et al. 1999) as they are often underestimated sources of new crop traits (Smale and Day-Rubenstein 2002) and indispensable elements required to restore agricultural activities, for example, after disaster situations.

An increasing concern about the loss of these landraces over the last decades has led to a heightened concentration on methods for the conservation of genetic resources in GeneBanks (ex situ conservation) (Bommer 1991). GeneBanks play an invaluable role in the conservation of landrace genetic resources, maintaining them as a crucial source of plant material for agriculture and food purposes, as well as a source of information about existing agrobiodiversity (Johnson 2008). The current situation of cereal collections, including its landraces in worldwide GeneBank system is presented in Table 1. Data show that cereal and landrace genetic resources have a wide distribution with a major number of the collection holders in European GeneBanks. 
Table 1 Regional distribution of GeneBanks, their cereals and cereals landraces collections (WIEWS 2012)

\begin{tabular}{lrrrrrrrrr}
\hline Geographical region & \multicolumn{9}{l}{$\begin{array}{l}\text { Number of GeneBanks maintaining cereals } \\
\text { and their landrace (LR) collections }\end{array}$} \\
\cline { 2 - 10 } & Total & Wheat & LR & Barley & LR & Oats & LR & Rye & LR \\
\hline Africa & 196 & 23 & 11 & 20 & 8 & 14 & 5 & 10 & 3 \\
Asia & 468 & 62 & 37 & 52 & 31 & 28 & 13 & 29 & 9 \\
Europe & 481 & 88 & 44 & 75 & 38 & 50 & 27 & 46 & 24 \\
Latin America and Caribbean & 425 & 32 & 9 & 24 & 6 & 15 & 2 & 7 & 2 \\
Oceania & 57 & 4 & 2 & 6 & 0 & 3 & 1 & 2 & 1 \\
North America & 88 & 11 & 7 & 11 & 4 & 6 & 3 & 5 & 3 \\
Total & 1715 & 220 & 110 & 188 & 87 & 116 & 51 & 99 & 42 \\
\hline
\end{tabular}

In an early global survey of cereal genetic resources, Bettencourt and Konopka (1990) identified a total of 911,983 accessions of barley, oat, rye and wheat, of which 119,795 (13\%) were clearly recorded as landraces. In a recent survey of available online information, Knüppfer (2009) documented a total of 1,284,231 accessions of Triticeae belonging to 35 genera (among them 12 hybrid genera) and almost 300 species, comprising $20 \%$ of the estimated world germplasm holdings maintained in 295 GeneBanks around the world.

Globally, an estimated 1,750 GeneBanks hold ex situ germplasm collections with approximately 7.4 million accessions, $24 \%$ of which are landraces. According to FAO (2010), these holdings are distributed as follows: Africa maintains $5 \%$ of the world's germplasm accessions; Asia, $31 \%$; Europe, $23 \%$; Latin America and the Caribbean, $14 \%$; Near East, $6 \%$; North America $10 \%$; and international and regional GeneBanks, $1.5 \%$ (Table 2). In addition, there are also substantial ex situ collections in the over 2,500 botanical gardens worldwide (FAO 2010).

Changes during the last ten years in the regional distribution and total numbers of available accessions are presented in Table 2 (FAO 1998, 2010). Nearly half (45 \%) of all accessions in GeneBanks are cereals, of which landraces account for $29 \%$ - wheat, rice, barley and maize comprise $76 \%$ of the total cereal and pseudo-cereal accessions in the ex situ collections. Interestingly, among cereal resources, $24 \%$ of wheat holdings are categorised as landraces/old cultivars, $23 \%$ for barley, $33 \%$ for maize, $14 \%$ for oats and $29 \%$ for rye (FAO 2010). From 1996 to 2007, more than 240,000 new accessions were collected and added to the ex situ collections. The vast majority of missions collected germplasm of direct national interest, particularly obsolete cultivars, landraces and related wild species. Cereals (35\%) were the main crop group targeted for collected materials (FAO 2010).

However, there are an uncertain number of duplicate accessions within and between collections (Diederichsen 2009). It is anticipated that unique accessions in the global collections account for only 25-30\% of the total holdings (or 1.9-2.2 million accessions), with the remainder being duplicates held either in the same or, more frequently, different collections (FAO 2010). These accessions need to be characterised and identified to create species core collections. Efficiency of conservation and management would be achieved through rationalising the collections by identifying and minimising unnecessary duplication (Dobrovolskaya et al. 2005). This is clearly a priority requirement. The first step in the detection of
Table 2 Trends in the number of genetic resources and germplasm accessions maintained in ex situ collections by the region according to FAO global surveys (FAO 1998, 2010)

\begin{tabular}{|c|c|c|c|c|}
\hline \multirow[t]{2}{*}{ Region } & \multicolumn{2}{|l|}{1998} & \multicolumn{2}{|l|}{2010} \\
\hline & Number of accessions & $\%$ & Number of accessions & $\%$ \\
\hline Africa & 353,523 & 5.7 & 354,193 & 4.8 \\
\hline Latin America, the Caribbean & 642,405 & 10.3 & $1,023,148$ & 13.8 \\
\hline North America & 762,061 & 12.2 & 708,107 & 9.5 \\
\hline Asia & $1,533,979$ & 24.5 & $2,294,060$ & 30.9 \\
\hline Europe & $1,934,574$ & 30.9 & $1,725,315$ & 23.3 \\
\hline Near East & 327,963 & 5.2 & 460,794 & 6.2 \\
\hline International and regional GeneBanks & 105,031 & 1.7 & 113,300 & 1.5 \\
\hline CGIAR & 593,191 & 9.5 & 741,319 & 10.0 \\
\hline TOTAL & $6,252,727$ & 100.0 & $7,420,236$ & 100.0 \\
\hline
\end{tabular}


possible duplicates is the verification of available passport data (van Hintum and Knüpffer 1995), followed by the evaluation of the accessions using agro-morphological and molecular traits. In the last three decades, the majority of efforts have been directed towards reversing the loss of crop diversity by collecting as many samples as possible from different geographic regions, especially from the rich centres of domestication and diversity. These efforts have not always relied upon good sampling and documentation practices, compromising the proper identification, conservation and use of germplasm accessions. Poor GeneBank management practices in the maintenance and regeneration of collected material throughout its lifetime within the GeneBank (Sackville Hamilton and Chorlton 1997) can also compromise the germplasm collection and future utilisation of the landraces. To address these problems and to minimise factors that might limit the value of a germplasm collection, both in improvement programmes and in diversity conservation, GeneBank management procedures have been proposed by an international consortium led by IPGRI (Engels and Visser 2003). Evidence shows that when proper procedures are followed, no dramatic change in the integrity or viability of cereal landrace samples are observed (Pita et al. 1998). However, problems affecting the genetic integrity and viability of cereal landraces, as well as contamination issues when samples are stored in GeneBanks have also been reported (Steiner et al. 1997; Parzies et al. 2000; Smale and Day-Rubenstein 2002; Chwedorzewska et al. 2006; Nagel et al. 2009).

The problems identified in the surveying and documentation of landraces call for a new approach to the evaluation of genetic resources held in GeneBank collections and the need for recording and maintaining data in a format that is easily, readily and universally available. The observed gaps in this domain may be the factors contributing to the limited number of publications evaluating or reviewing cereal landrace genetic resources.

\section{Overview of cereal landraces in global information systems}

Dissemination of the information on availability of plant genetic resources plays a critical role in the sustainable use of crop diversity and, consequently, the sustainable future of mankind. Several actions have been initiated to ensure requested information is readily available to interested parties and several information systems dealing with genetic resources data have been established. FAO maintains the WIEWS on Plant Genetic Resources (http://apps3.fao.org/ wiews/wiews.jsp). Bioversity International also maintains the EURISCO Catalogue (http://eurisco.ecpgr.org/), on behalf of the Secretariat of ECPGR, which automatically receives data from 42 National Focal Points of the
European NIs and provides access to ex situ PGR information in Europe (Dias 2009), and the SINGER (http://singer. cgiar.org), on behalf of the CGIAR, a catalogue which provides access to information on the PGRFA maintained in the CGIAR Centres. While WIEWS maintains metadata, data on germplasm collections, EURISCO and SINGER maintain data at accession level, so-called passport data.

The amount of data in the EURISCO Catalogue has clearly evolved over time. In 2006, the Catalogue included over 8,000 species, but there are currently (EURISCO 2012) more than 35,000 species ( $338 \%$ increase). Moreover, these species were maintained in 218 GeneBanks in 2006 and 318 GeneBanks in 2012 (46\% increase). Approximately $15 \%$ of the accessions in 2006 were reported to be landraces and $25 \%$ in 2010 (Dias et al. 2006; Dias 2010), a situation that remains unchanged (EURISCO 2012).

The SINGER system (to be integrated into GENESYS) also maintains accession-level passport data on a total of 751,717 accessions of 3,619 species, of which $43.6 \%$ are reported to be landraces. Cereals account for $52 \%$ of the total holdings including: rice, $19 \%$; wheat, $19 \%$; barley, $6 \%$; sorghum, $5 \%$; and maize, $4 \%$. Although only $8 \%$ of the total CGIAR germplasm holdings originate from Europe, almost half $(52.2 \%)$ are reported as landraces, representing $9 \%$ of the total number of landraces maintained by the network. SINGER holds data on the germplasm collections of 11 CGIAR GeneBanks and the AVRDC. However, the data regarding the number of accessions representing landraces $(44 \%)$ is quite low when compared with the $73 \%$ of landraces and CWR held in CGIAR collections, as referred by Koo et al. (2003). The discrepancy in the number of landraces in CGIAR collections can be attributed to the differences in accession labels or to a limited access to the germplasm documentation. Although these systems are important entry points to access information on germplasm collections around the world, almost all information is limited to origin and collecting data. Information about the accession type, (i.e. if it is a landrace), is not always provided.

For the preparation for this overview, the WIEWS system was utilised. This system provided the identification and analysis of the status of genetic resources of cereal landraces maintained in GeneBanks around the world. Special attention was paid to cereal collections of wheat, oat, rye and barley. A brief description of this analysis is given below.

\subsection{Wheat landraces in GeneBanks}

Bettencourt and Konopka (1990) in an early global survey of cereal genetic resources identified a total of 529,577 accessions of wheat, of which 83,377 accessions (15.7\%) were identified as landraces. This material was maintained in 102 germplasm collections in 47 countries. In a recent 
survey of available online information, Knüpffer (2009) reported a total of 732,262 accessions of wheat maintained in 223 holding institutions. Of the total number of accessions, 167,133 were identified only at the genus level and 565,129 at the species level. FAO (2010) identified a total of 229 institutes holding 856,168 wheat accessions, of which $24 \%$ are identified as landraces.

Based on the first and the latter sources of information (Knüpffer's paper was made available in June 2009 while the FAO report was published in October 2009), it is worth noting that during the last 19 years (1990-2009), the number of accessions and holding institutions has increased substantially, by 62 and $128 \%$, respectively. An example of a wheat landrace cultivated on the Archipelago of Madeira, Portugal, is presented in Fig. 2.

For the purposes of this overview, information provided by WIEWS (2012) was used to perform a more detailed analysis of the status of wheat landraces in the global system of GeneBanks. A total of 859,472 accessions of wheat germplasm were found to be maintained in GeneBanks in 90 countries within Europe, America, Asia, Africa and Oceania. However, only 225,120 accessions (26\% of the total) were classified as wheat landraces or related accessions (accessions selected from landraces), while the remaining wheat accessions were identified as improved cultivars, breeders' lines or were of unknown status. GeneBanks from 61 countries reported holding wheat landraces in their germplasm collections. Among them, 209,469 accessions were classified as true Triticum sp. landraces, representing $93 \%$ of the total number of wheat landrace accessions. The remaining 15,651 accessions were simultaneously and indiscriminately classified as landraces, wild

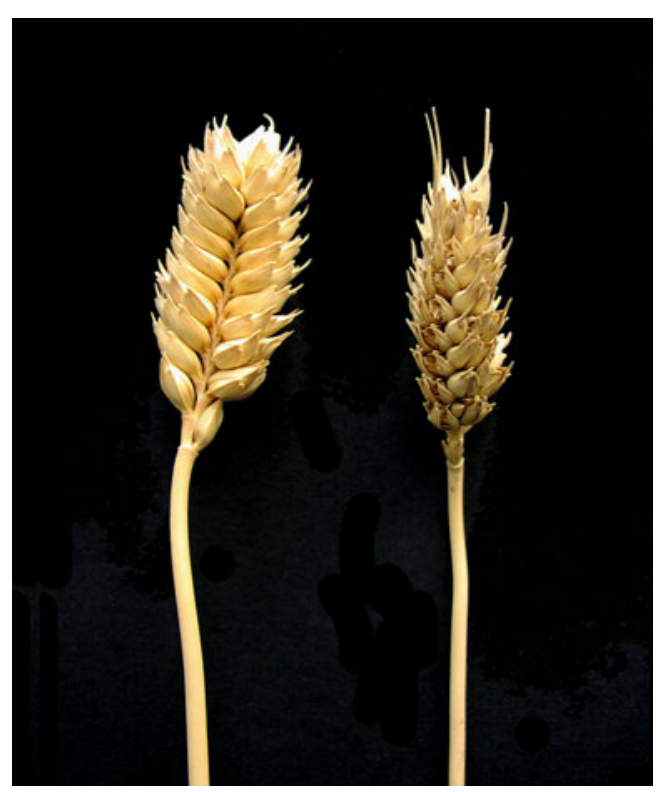

Fig. 2 Wheat landrace "Rapadinho" from the Archipelago of Madeira, Portugal species, cultivars, advanced cultivars, genetic stocks or even breeders' lines, and represented $2 \%$ of the total accessions. The top six wheat germplasm collections included: CIMMYT, Mexico, which maintains a total of 111,396 accessions, $31 \%$ of which are identified as landraces; the National Small Grains Germplasm Research Facility (NSGC) at the USDA, ARS, USA, with 57,788 accessions, $57 \%$ of which are classified as landraces; the Institute of Crop Germplasm Resources, Chinese Academy of Agricultural Sciences (ICGR-CAAS), P.R. China, maintaining a total of 41,030 accessions (no accessions identified as landraces); the NBPGR, India, with a total of 35,889 accessions, of which only $2 \%$ are classified as landraces; ICARDA, Syria, maintaining a total of $34,983,75 \%$ of which are landraces; and the NIAS, Japan, maintaining a total of 34,652 with only $4.4 \%$ classified as landraces. The European Wheat Database (EWDB) currently (European Wheat database EWDB 2012) consists of 160,262 records of which, 38,865 identified as landraces can be accessed at http://genbank.vurv.cz/ewdb/default.htm. The EURISCO Catalogue contains data on 169,868 accessions of wheat maintained in the European GeneBanks, of which 44,978 are traditional cultivars/landraces. The VIR collection is the largest and most complete, with 34,253 accessions of Triticum (EURISCO 2012).

Based on the WIEWS data and the other available information, the authors concluded that the VIR wheat collection should be considered the best documented among the major collections, as all the accessions are identified at species, subspecies or even at the botanical varieties taxonomical level. Triticum aestivum, Triticum turgidum, Triticum durum, Triticum monoccocum and Triticum dicoccum are the major wheat species easily recognised in the VIR collection. All species and accessions contained in VIR are duplicated in the German Federal GeneBank (GFG), Gatersleben; however, the number of wheat species in both collections is different, a situation that seems to be related to the taxonomic nomenclature systems used in the documentation (van Slageren 1994; Dorofeev et al. 1979; Kimber and Feldman 1987) as shown by Dobrovolskaya et al. (2005).

Differences in the documentation and identification of the accessions made available by GeneBanks and the limitations of the WIEWS do not allow for an in-depth comparison of the landraces in germplasm collections from different GeneBanks, limiting our ability to offer a more comprehensive global overview on the actual situation of wheat landrace resources. This situation also points to the need to standardise documentation requirements for the germplasm collections. Despite the detected limitations, the wheat collection from GFG, Gatersleben, was analysed using WIEWS data. The WIEWS collection was selected based on the taxonomic identification of accessions and its size (medium). The collection's structure and composition, 
as found in the analysis, are presented in Table 3. Based on the differences between the species' total number of accessions and the number of landrace accessions, one can predict the structure of materials consisting of breeding and improved cultivar accessions, which is fairly important for breeding programmes associated with the GeneBanks. Information regarding the CIMMYT and the CGIAR collections, including the structure and the percentage of genetic resources representing wheat landraces were detailed by Koo et al. (2003) and Pardey et al. (2001). According to this information, the CIMMYT and the ICARDA wheat collections are the most important sources of landrace resources for wheat. Pardey et al. (2001) gave an account of the efforts to increase the amount of genetic resources conserved ex situ based on the evolution of the CIMMYT wheat collection, which between 1980 and 1997 grew almost 16-fold for bread wheat, reaching 71,171 accessions, and seven times for durum wheat, reaching 15,490 accessions. These cited works also presented an estimate of the costs of short- (annual) and long-term germplasm conservation, as well as the operating costs of a modern GeneBank for the CIMMYT germplasm collections (Pardey et al. 2001) or those of the CGIAR GeneBanks (Koo et al. 2003). These costs determine the need to optimise the size of the germplasm collections by limiting the amount of duplicate accessions. It must be emphasised, however, that an accurate figure for the number of duplicates in the collections cannot be determined, as this issue has been a subject of only a limited study. Nonetheless, it is estimated that only between 25 and $30 \%$ of the total holdings conserved in the GeneBanks are unique. Careful attention must be paid when determining whether or not the accessions are unique since Dobrovolskaya et al. (2005) have shown that identification of the duplicates based only on one criterion, e.g. accession number, provenance, accessions' common names or even taxonomic identification, could lead to the elimination of useful and unique accessions. Efforts to improve our knowledge about genetic resources held in the GeneBanks and the creation of core germplasm collections are urgently needed. This recommendation should be extended to all cereal crops and their landraces addressed in this overview.

\subsection{Barley landraces in GeneBanks}

A survey of the global cereal holdings (Bettencourt and Konopka 1990) identified a total of 283,138 accessions of barley maintained in 94 germplasm collections in 47 countries; 32,316 of these accessions (11.4\%) were identified as landraces. More recently, Knüpffer (2009), after surveying available online information resources, documented a total of 466,531 accessions of barley, of which 63,511 accessions were identified only at the genus level, while 390,097 accessions were identified at the species level. The material was maintained in 199 holding institutions worldwide. FAO (2010) identified a total of 470,470 accessions of barley germplasm, of which $23 \%$ are classified as landraces maintained in 204 GeneBanks worldwide. Like wheat, a striking increase in both the number of barley accessions conserved and the number of holding institutions (66 and $117 \%$, respectively) has been observed during the last 19 years (1990 2010). An example of a barley landrace cultivated on Santorini Island, Greece, is presented in Fig. 3.

Two hundred GeneBanks in 84 countries within Europe, America, Asia, Africa and Oceania maintain a total number of 471,252 barley accessions, of which 136,155 accessions have been classified as landraces. However, the number of accessions undoubtedly classified as barley landraces reached 108,949 accessions, or $80 \%$ of the total (WIEWS 2012). EURISCO provides records of 99,692 accessions of Hordeum from 35 European countries, of which 25,548 from 25 countries were classified as traditional cultivars/ landraces. The European Barley Database (EBDB) currently includes data on about 155,518 accessions from 23 European countries. This database also includes information on 38,335 additional accessions from three non-European GeneBanks (Australian Winter Cereals Collection (AWCC), Tamworth, Australia; ICARDA, Syria; and Barley Germplasm Centre, Kurashiki, Japan). In addition, 1,298 accessions from the IBCC are also well documented.

According to FAO (2010), the top four barley landrace collections are located at: the Plant Gene Resources of Canada (PGRC), Saskatoon Research Centre, Agriculture and Agri-Food Canada, Canada, which holds a total of 40,031 accessions, $41 \%$ of which have been determined to be landraces; the NSGC, USA, maintaining 29,874 accessions, of which $56 \%$ are classified as landraces; the EMBRAPA Recursos Genéticos e Biotecnologia (CENARGEN), Brazil, collection conserving 29,227 accessions (specific information about accession types is not available); and ICARDA, Syria, maintaining a collection of 26,679 accessions, of which landraces account for $67 \%$ of the total germplasm holdings.

It is the opinion of the authors that the best documented barley germplasm collection is maintained by the GFG, Gatersleben, which houses 22,093 accessions and where almost all accessions, many of them classified as landraces, are taxonomically identified at the level of variety or convariety (e.g. H. vulgare convar. deficiens, with 26 accessions). The structure and composition of this barley collection is presented in Table 4. Based on differences between the species' total number of barley accessions and the number of landrace accessions, it is possible to predict the structure of the material constituting breeding and improved cultivar accessions. According to Pardey et al. (2001), barley genetic resources conserved ex situ in the CIMMYT collection have grown 4.3 times from 1980 to 1997, 


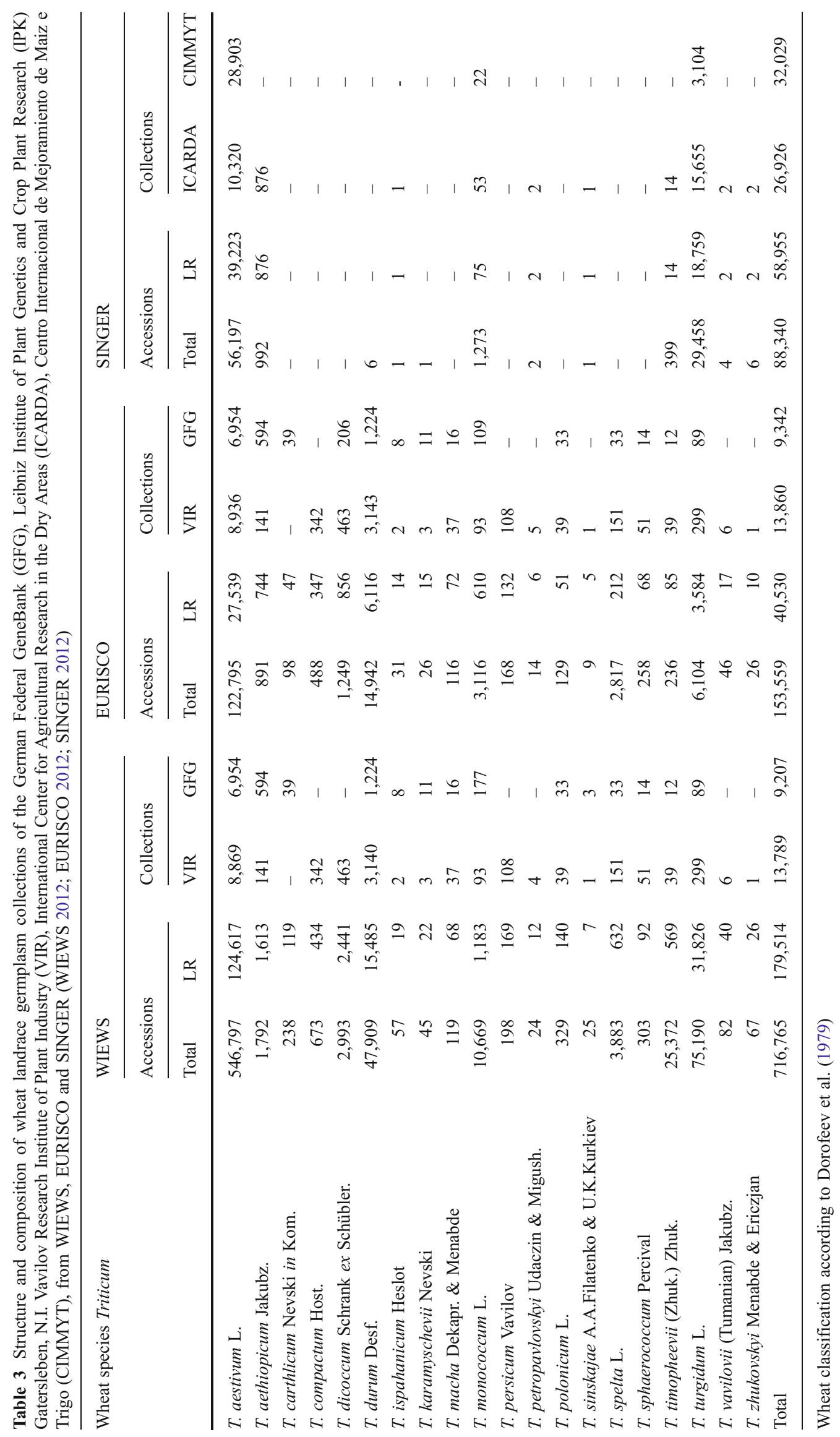




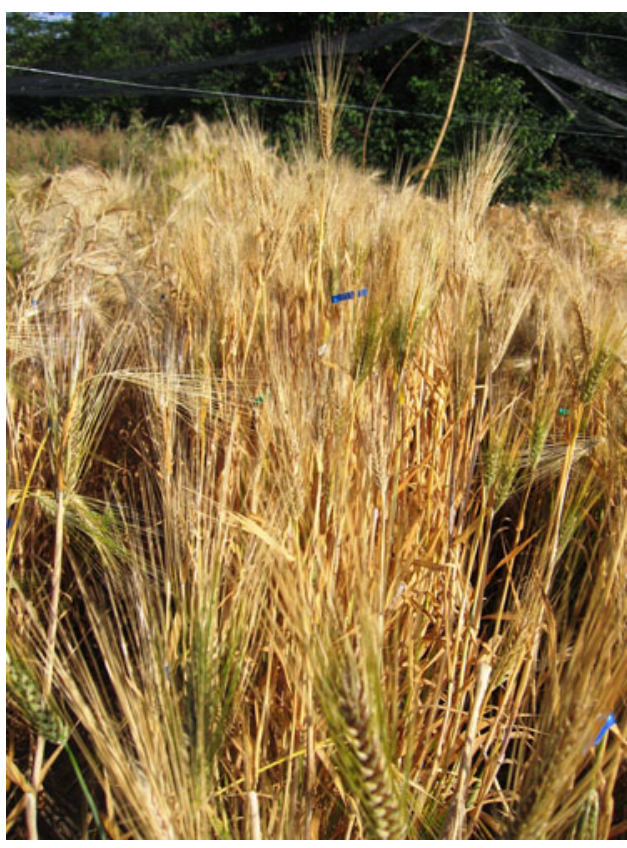

Fig. 3 Barley landrace from Santorini Island, Greece

reaching 9,084 accessions. However, FAO (2010) reported that a decrease in global barley holdings was observed from 1998 to 2010 (485,000 to 466,531, respectively).

\subsection{Oat landraces in GeneBanks}

An early survey of cereal genetic resources (Bettencourt and Konopka 1990) listed 50 GeneBanks in 33 countries, conserving a total of 84,493 oat accessions, of which only 1,742 ( $2 \%)$ were classified as landraces. The status of the oat genetic resources reported in a global survey (FAO 2010) are as follows: a total of 130,653 accessions, of which $14 \%$ are classified as landraces maintained in 124 GeneBanks. A simple comparison between the two surveys indicates a very

Table 4 Structure and composition of barley landrace germplasm collections of the German Federal GeneBank (GFG), Leibniz Institute of Plant Genetics and Crop Plant Research (IPK) Gatersleben, N.I. Vavilov Research Institute of Plant Industry (VIR), International considerable increase of $75 \%$ in the number of accessions held, as well as in the number of holding institutions (156\%).

A total of 65 countries in Europe, America, Asia, Africa and Oceania maintain 131,355 accessions of oat (Avena sp.) in the germplasm collections (WIEWS 2012). According to the WIEWS data, GeneBanks from 41 countries have reported oat landraces in their collections. However, only 32,298 accessions stored in these collections are classified as landraces or related accessions, while the remaining accessions are classified as improved cultivars, breeder's lines or as unidentified materials. Among them, 18,588 accessions are classified as true oat landraces, representing $14 \%$ of the total number of oat accessions. The remaining 13,641 accessions included in the oat collections are classified as CWRs, cultivars, advanced cultivars, mutant lines, introgressed forms or breeders' lines, representing $42 \%$ of the total number of the accessions. EURISCO provided records of 34,394 accessions of Avena from 30 European countries, of which 10,541 accessions from 23 countries are traditional cultivars/landraces. Also, the EADB contains passport data for 32,657 accessions representing the Avena collections from 29 European contributors (http://eadb.jki. bund.de/bgrc/eadb/avena.htm).

The major collections of oat landraces are located in Canada, Russian Federation, USA and Germany. The PGRC, Saskatoon Research Centre, Agriculture and AgriFood Canada maintain the biggest oat collection, with 27,676 accessions, of which only $12 \%$ are classified as landraces (FAO 2010). These figures do not differ from those published by Diederichsen $(2008,2009)$ who reported 27,000 accessions, with 10,000 belonging to $A$. sativa $\mathrm{L}$. of which the majority are classified as landraces. The VIR oat collection, with 11,857 accessions (41\% landraces) is the best documented collection, where all accessions are identified at the species level. The NSGC, USA has a collection of 21,195 oat accessions ( $14 \%$ landraces). The fourth largest

Center for Agricultural Research in the Dry Areas (ICARDA) and Centro Internacional de Mejoramiento de Maiz e Trigo (CIMMYT), obtained from WIEWS, EURISCO and SINGER (WIEWS 2012; EURISCO 2012; SINGER 2012)

\begin{tabular}{|c|c|c|c|c|c|c|c|c|c|c|c|c|}
\hline \multirow[t]{3}{*}{ Barley Species Hordeum } & \multicolumn{4}{|l|}{ WIEWS } & \multicolumn{4}{|c|}{ EURISCO } & \multicolumn{4}{|c|}{ SINGER } \\
\hline & \multicolumn{2}{|c|}{ Accessions } & \multicolumn{2}{|c|}{ Collections } & \multicolumn{2}{|c|}{ Accessions } & \multicolumn{2}{|c|}{ Collections } & \multicolumn{2}{|c|}{ Accessions } & \multicolumn{2}{|c|}{ Collections } \\
\hline & Total & LR & VIR & GFG & Total & LR & VIR & GFG & Total & LR & ICARDA & CIMMYT \\
\hline H. deficiens Steud & 53 & 41 & - & - & - & - & - & - & - & - & - & - \\
\hline H. distichon $\mathrm{L}$. & 2,663 & 1,675 & - & - & 28 & 3 & - & - & - & - & - & - \\
\hline H. irregular E. Aberg and Wiebe & 330 & 330 & - & - & - & - & - & - & 320 & - & - & - \\
\hline H. vulgare L. & 393,575 & 122,037 & 4,126 & 8,602 & 84,747 & 21,747 & 4,126 & 8,602 & 40,718 & 18,148 & 17,760 & 388 \\
\hline Total & 396,621 & 124,083 & 4,126 & 8,602 & 84,775 & 21,750 & 4,126 & 8,602 & 41,038 & 18,148 & 17,760 & 388 \\
\hline
\end{tabular}

Barley classification according to Brummitt and Powell (1992) 
collection, in terms of number of accessions maintained, is held by the GeneBank, Leibniz Institute of Plant Genetics and Crop Plant Research (IPK), Germany, with a total of 4,799 oat accessions, $33 \%$ of which are classified as landraces.

Different systems of resource documentation, as well as differences in taxonomic systems and the limitations of the WIEWS system, prevented comparative surveys of landrace collections from different GeneBanks being conducted. Based on the WIEWS data, the oat collection of VIR (Table 5) was analysed. This is an exemplary collection characterised by outstanding taxonomic classification of the accessions. In this collection, the difference between the total number of accessions and the number of landrace accessions indicates the material representing breeding and improved accessions.

Interesting conclusions can be drawn when comparing data from the First Report on the State of the World's Plant Genetic Resources for Food and Agriculture (FAO 1998) with the second one (FAO 2010). While the first survey stated that only $2 \%$ of accessions were identified as landraces/old cultivars (the same figure reported by Bettencourt and Konopka 1990) and $6 \%$ as advanced cultivars/breeding lines, the latter survey reported $14 \%$ of the accessions as landraces and $13 \%$ as breeding lines/advanced cultivars. Again, there is a discrepancy between the global holdings provided in the first status report (FAO 1998) and the second report (FAO 2010), showing a considerable decline in the number of oat accessions maintained, 223,287 and 130,653, respectively. The reasons for such decline in the number of accessions conserved are not well identified and could pinpoint a threat to the conservation of these resources.

\subsection{Rye landraces in GeneBanks}

An early survey identified a total of 14,775 accessions of rye, maintained in 38 germplasm collections in 26 countries, of which 2,360 accessions (16\%) were reported to be landraces (Bettencourt and Konopka 1990). Knüpffer (2009), in a survey of available online information, documented a total of 21,550 accessions conserved in 94 holding institutes, of which 2,069 and 19,475 accessions are identified at the genus and species levels, respectively. While the first status report (FAO 1998) listed 27,132 accessions of rye (1\% classified as landraces/old cultivars), the second status report (FAO 2010), documented a total of 21,192 accessions, maintained in 94 GeneBanks worldwide, with $29 \%$ of the conserved material classified as landraces. Comparing the figures provided in the 1990 survey (Bettencourt and Konopka 1990) with the more recent one (FAO 2010), a sharp increase in both the number of accessions held globally ( $43 \%$ ) and the number of holding institutions $(150 \%)$ can be noted.

According to FAO (2010), the top five rye germplasm collections are held in the following institutes: VIR, Russian Federation, which maintains a collection of 2,928 accessions ( $34 \%$ landraces); the IPK, Germany which maintains a total of 2,392 accessions (27\% landraces); the IHAR, Poland, which conserves a total of 2,266 accessions (12\% landraces); the NSGC, USA, which conserves 2,106 accessions (77\% landraces); and the PGRC, Agriculture and Agri-Food Canada, Canada which stores 1,446 accessions (23\% landraces). Although the rye collection at CIMMYT is one of the smallest cereal germplasm collections, according to Pardey et al. (2001), its genetic resources grew by 6.1 times between 1990 and 1997, reaching 202 accessions.

Generally, the rye collections of NSGC, USA and VIR, Russian Federation, are reliably documented, with all accessions identified at the species or subspecies level. Again, different GeneBank approaches to the documentation and identification of accessions and the limitations of the WIEWS system did not allow surveys based on species designations or resources classification to be conducted
Table 5 Structure and composition of oat landrace germplasm collections of the German Federal GeneBank (GFG), Leibniz Institute of Plant Genetics and Crop Plant Research (IPK) Gatersleben, N.I. Vavilov Research Institute of Plant Industry (VIR), International Center for
Agricultural Research in the Dry Areas (ICARDA) and Centro Internacional de Mejoramiento de Maiz e Trigo (CIMMYT), from WIEWS, EURISCO and SINGER (WIEWS 2012; EURISCO 2012; SINGER 2012)

\begin{tabular}{|c|c|c|c|c|c|c|c|c|c|c|c|c|}
\hline \multirow[t]{3}{*}{ Oat Species Avena } & \multicolumn{4}{|l|}{ WIEWS } & \multicolumn{4}{|c|}{ EURISCO } & \multicolumn{4}{|c|}{ SINGER } \\
\hline & \multicolumn{2}{|c|}{ Accessions } & \multicolumn{2}{|c|}{ Collections } & \multicolumn{2}{|c|}{ Accessions } & \multicolumn{2}{|c|}{ Collections } & \multicolumn{2}{|c|}{ Accessions } & \multicolumn{2}{|l|}{ Collections } \\
\hline & Total & LR & VIR & GFG & Total & LR & VIR & GFG & Total & LR & ICARDA & CIMMYT \\
\hline A. abyssinica Hochst. & 690 & 113 & 36 & 6 & 149 & 114 & 36 & 6 & - & - & - & - \\
\hline A. byzantina $\mathrm{K}$. Koch & 2,015 & 960 & 360 & 302 & 1,887 & 968 & 360 & 302 & - & - & - & - \\
\hline A. nuda $\mathrm{L}$. & 1,784 & 19 & - & 2 & 210 & 34 & - & 2 & - & - & - & - \\
\hline A. sativa $\mathrm{L}$. & 70,845 & 18,222 & 4,301 & 1,185 & 26,427 & 8,912 & 4,301 & 1,185 & 675 & 35 & 35 & - \\
\hline A. strigosa Schreb. & 845 & 461 & 125 & 7 & 524 & 284 & 125 & 7 & - & - & - & - \\
\hline Total & 76,179 & 19,775 & 4,822 & 1,502 & 29,197 & 10,312 & 4,822 & 1,502 & 675 & 35 & 35 & 0 \\
\hline
\end{tabular}

Classification according to Brummitt and Powell (1992) 
and compared among landraces stored in different GeneBanks. Based on the WIEWS data, the VIR rye collection was analysed; the selection of this landrace collection was based on the accessibility of taxonomic data and accessions or resources classification (Table 6). The differences between the species' total number of accessions and the number of accessions classified as landraces provides an idea of the material representing breeding and improved cultivars. Similar to the other crops reviewed herein, the difference between the total number of rye accessions and the number of landrace accessions represents the material considered as breeding and improved cultivar accessions.

An enormous discrepancy in the number of accessions and percentage of landraces could be observed in previous surveys (Bettencourt and Konopka 1990; FAO 1998, 2010; Knüpffer 2009). For example, while Bettencourt and Konopka (1990) referred the existence of 14,775 accessions of rye, of which 2,360 (16\%) were landraces, FAO (2010) reports the existence of 21,192 accessions, $29 \%$ of which are reported as landraces, $22 \%$ as breeding lines, $15 \%$ as advanced cultivars, $6 \%$ as wild species and $27 \%$ of uncertain status. The EURISCO Catalogue provides records of 13,283 accessions of Secale sp. from 29 European countries, of which 3,877 accessions from 21 countries are traditional cultivars/landraces. Also, the European Secale Database (ESDB) contains passport data on 13,187 accessions maintained in 39 European institutions (http://www.ihar.edu.pl/ gene_bank/index_en.php). According to FAO (2010), the largest rye collection is maintained by VIR, which comprises $14 \%$ of all accessions maintained in the germplasm collections worldwide.

\section{Conclusions}

The present work attempts to review and systematise the scientific knowledge about the genetic resources of cereal landraces conserved in GeneBanks worldwide. In the 1970s, the traditional role of GeneBanks began to evolve and new functions and tasks have since been added to their original purpose to conserve plant materials for breeding programmes. In the past, plant breeders searching for accessions with specific traits (i.e. resistance genes) accounted for the majority of GeneBank users. Today, new users, including farmers, nature museums and growers of landraces or conservation varieties also request access to the conserved material. These new users do not focus exclusively on crop germplasm traits, but are also interested in the landraces, their history and the traditional knowledge associated with the management and use of such materials. At the same time, several changes in key climatic features (i.e. drought) impacting agricultural production have the potential to increase the importance of cereal landraces and genetic resources conserved in GeneBanks, as these materials provide critical genes for the development of new and adapted cultivars. Periodically, the costs and economic benefits associated with germplasm conservation in the GeneBanks are raised; criticism often centres on the high number of samples held in ex situ collections, the high cost of their conservation and the scarcity of evidence of generated economic benefits. Pardey et al. (2001) and Koo et al. (2003) made an attempt to determine the cost of genetic resources conservation at CIMMYT and the CGIAR Centres. Pardey et al. (2001) reported that conservation costs are often crop-specific crop. For example, the costs per accession for open-pollinating crops, for instance maize, are much higher compared with self-pollinating crops like wheat. Nevertheless, the authors are not aware of any attempts to determine the economic value and benefits of crop diversity conservation. Determining the economic value of germplasm, in the context of genetic resources for food and agriculture, is a complex task. The economic value should be determined by the benefits provided from the germplasm, not by the simple attribution of a monetary value. The value depends on the level of usefulness and the types of use each individual associates with the genetic resources, either in a scientific, development, cultural or anthropological context. Giving a concrete value to crop landrace genetic resources is not a straightforward process, although it is possible to describe the associated benefits. The most
Table 6 Structure and composition of rye landrace germplasm collections of the German Federal Genebank (GFG), Leibniz Institute of Plant Genetics and Crop Plant Research (IPK) Gatersleben, N.I. Vavilov Research Institute of Plant Industry (VIR), International Center for
Agricultural Research in the Dry Areas (ICARDA), Centro Internacional de Mejoramiento de Maiz e Trigo (CIMMYT), from WIEWS, EURISCO and SINGER (WIEWS 2012; EURISCO 2012; SINGER 2012)

\begin{tabular}{|c|c|c|c|c|c|c|c|c|c|c|c|c|}
\hline \multirow[t]{3}{*}{ Rye species Secale } & \multicolumn{4}{|c|}{ WIEWS } & \multicolumn{4}{|c|}{ EURISCO } & \multicolumn{4}{|c|}{ SINGER } \\
\hline & \multicolumn{2}{|c|}{ Accessions } & \multicolumn{2}{|c|}{ Collections } & \multicolumn{2}{|c|}{ Accessions } & \multicolumn{2}{|c|}{ Collections } & \multicolumn{2}{|c|}{ Accessions } & \multicolumn{2}{|l|}{ Collections } \\
\hline & Total & LR & VIR & GFG & Total & LR & VIR & GFG & Total & LR & ICARDA & CIMMYT \\
\hline S. cereale L. & 18,283 & 7,662 & 1,005 & 398 & 11,732 & 3,527 & 1,005 & 398 & 441 & 89 & 4 & 85 \\
\hline Total & 18,283 & 7,662 & 1,006 & 662 & 11,732 & 3,527 & 1,006 & 398 & 441 & 89 & 4 & 85 \\
\hline
\end{tabular}

Classification according to Brummitt and Powell (1992) 
obvious benefit is the one that derives from direct use: to produce food, fibre and/or to help create new varieties of crops out of these genetic resources. Other, less evident, benefits are related to the efforts of farmers to domesticate and maintain crops and the development of landraces through many years of selection, actions which support environmental, scientific, ethnographic and other services (Kaplan 1998). Further benefits are associated with the actual efforts to mitigate climatic changes. Smale and Koo (2003) related the value of plant genetic resources to the use value, as the value derives not from the assurance that plant genetic resources are safely maintained (non-use value), but from the fact that these resources are believed to embody genes and gene combinations of current and future use to society. Barbier et al. (1995) pointed out that if landraces have never been used, their value could be determined by the usefulness of the conserved germplasm for future generations. To attribute an economic value to genetic resources, in the actual context of conservation, economic studies would need to be conducted on a case-bycase basis, as the services provided and the potential of the materials conserved vary significantly according to species/ crop, conservation conditions, type of material, quality and quantity available and where they are maintained (i.e. country hosting the GeneBank and collections). Some authors have made attempts to estimate the value accrued by the use of plant genetic resources. Frisvold et al. (2003) estimated the welfare gains of genetic improvements in major US crops as annual benefits ranging from US\$ 400-600 million. Of this, the US accrues $44-60 \%$ of the profit; other developed countries accrue $24-34 \%$; and developing and transitional economies capture $16-22 \%$ of the welfare gain.

Nowadays, there is an abundance of valuable data regarding plant material collected and conserved in the GeneBanks worldwide. However, these data are often not readily available for potential users due to the lack of unified organisation, structure and registration. Typically, only general information (e.g. passport data) about the resources conserved in the GeneBanks is provided, while data regarding the traits or the history of landraces are often absent. This problem is a result of the extremely fast growth rate of resources conserved in the GeneBanks worldwide (7.4 million accessions are now conserved) (FAO 2010) and the slower development of personnel and limited availability of financial resources for the characterisation, evaluation and documentation programmes. The sustainable use of genetic resources maintained in the germplasm collections for breeding or training purposes needs to be enhanced, and the use of molecular and biotechnological tools in the screening and characterisation could accelerate this process (Ferreira 2006). However, to achieve this goal, an effort to link molecular marker analysis with specific traits or targeted landrace qualities is required. However, critical deficiencies detected in the knowledge of cereal landrace genetic resources conserved ex situ in the main GeneBanks may hamper this achievement. Similar issues were identified in the evaluation of the efficiency of sampling methods and conservation strategies; this is linked to the absence of national surveys and inventories of cereal landraces, as well as the lack of a common understanding of the landrace concept and knowledge of the nature, genetic structure and variability of landraces. The discussion on the concept of landrace is far from over. The species definition of landraces is needed, as the scope and structure of the resources category can depend on several factors, including history and cultivation practices, agronomic traits and species reproductive biology (Chebotar et al. 2003). The overall analysis of data on cereal landraces existing in GeneBank information systems and the combined data accessed through metadata systems have highlighted limitations in the identification of landraces and genetic resources in terms of the origin of traits, as well as in the identification of duplicates. The global absence of information about the use of genetic resources in the worldwide GeneBank systems contrasts with data revealing the high demand for genetic resources from select GeneBanks, such as the NPGS, USA (Smale and Day-Rubenstein 2002) and the CGIAR and CIMMYT (Pardey et al. 2001; Koo et al. 2003) collections. The national or international breeding programmes associated directly with these organisations appear to contribute to the high popularity of their genetic resources.

GeneBanks ought to expand their mandates beyond the traditional collection of information and must undertake efforts to share and exchange germplasm information using different mechanisms and channels to promote unlimited use of conserved materials by the interested entities, including researchers, breeders, decision makers and students. Such an approach would guarantee that these valuable and unique materials are effectively utilised for the further development of sustainable agriculture, local economies, food security and quality through improved cultivars and the use of traditional landraces and CWRs with traits of interest for adaptation to climate change.

New GeneBank users could play an important and complementary role in the conservation of traditional resources and, in this way, support GeneBanks in the management of the cereal landrace collections. The interaction among GeneBanks and those who are motivated to preserve traditional seeds will be fundamental to overcome some of the problems facing GeneBanks with regard to seed regeneration, such as genetic drift, pollution and erosion of landraces (Chebotar et al. 2003). However, the major advantage of supporting these new users in accessing and utilising the germplasm conserved in GeneBanks is the possibility of the continuation of the evolutionary processes of the landraces. An effective conservation strategy must take into consideration both conservation and evolution. Therefore, ex situ conservation alone cannot provide the lasting benefits that accrue from the conservation of habitats and agro-systems 
rich in diversity (Swaminathan 2002). Cereal landraces cannot be exclusively conserved as seed samples maintained under ex situ conditions in the GeneBanks. Currently, several programmes aim to maintain agro-biodiversity components, including landraces, applying on-farm and in situ conservation methods where crops are managed using the same agricultural techniques, in the same agroenvironmental conditions and the same anthropogenic and natural selection pressures under which they have evolved (Maxted et al. 1997; Holubec et al. 2010; Newton et al. 2010). A comparison between ex situ and in situ conserved landraces should take into account the conditions under which either conservation system is practiced. The exchange, introduction and mixing of diverse materials by farmers may result in increased diversity within a landrace. On the other hand, an inefficient regeneration sampling system followed by unintended selection and genetic drift could cause a decline in landrace genetic diversity over time (Parzies et al. 2000).

Both the Convention on Biological Diversity (CBD 1993) and the International Treaty on PGRFA (ITPGRFA 2004) recognised the enormous contribution of farmers to maintaining the crop diversity that provides the food stock for the world and contributes to the development and conservation of genetic resources. Sharing of benefits and raising awareness of the value of cereal landraces are the most effective ways to promote their conservation and to ensure the continued availability and sustainable utilisation of plant genetic resources. There is, therefore, a pressing need to create an economic stake in conservation. In general, the issue of benefit-sharing still needs further investigation and to receive due attention from those formulating legal measures for the implementation of the CBD and the ITPGRFA. Some benefit-sharing methods might involve the promotion of processes aimed at keeping cereal landraces in cultivation, supporting seed production and distribution and developing new markets for local varieties and their products. In 1998, the European Council ruled that genetic resources threatened by genetic erosion and adapted to local or regional conditions can be marketed under specific conditions, while the Commission Directive 2008/62/EC of 20 June 2008 allows for certain derogations in order to promote the sustainable use and conservation of agricultural landraces naturally adapted to local conditions and threatened by genetic erosion. This Commission Directive should, hopefully, provide the legal basis for the local marketing of seeds from genetic resources, which would encourage and support the on-farm conservation of landraces and promote their sustainable utilisation.

Acknowledgements This work was support by the European Community, through the INTERREG IIIB and MAC programmes, research projects Germobanco Agrícola da Macaronesia and AGRICOMAC. This paper was edited by Olga Spellman (Bioversity International)

\section{References}

Agrawal RC, Behera D, Saxena S (2007) genebank Information Management System (GBIMS). Comput Electron Agric 59:90-96

Aguiriano E, Ruiz M, Fité R, Carrillo JM (2006) Analysis of genetic variability in a sample of the durum wheat (Triticum durum Desf.) Spanish collection based on gliadin markers. Genet Resour Crop Evol 53:1543-1552

Allard RW (1970) Population structure and sampling methods. In: Frankel OH, Bennett E (eds) Genetic resources in plants-their exploration and conservation. Blackwell, Oxford, pp 97-107

Altieri MA (2003) The sociocultural and food security impacts of genetic pollution via transgenic crops of traditional varieties in Latin American centers of peasant agriculture. Bull Sci Technol Soc 23:350-359

Assefa A, Labuschange MT (2004) Phenotypic diversity in barley (Hordeum vulgare L.) landraces from north Shewa in Ethiopia. Biodivers Conserv 13:1441-1451

Barbier EB, Brown G, Dalmozzone S et al (1995) The economic value of biodiversity. In: Heywood VH (ed) Global biodiversity assessment. United Nations Environment Program. Cambridge University Press, Cambridge, pp 820-914

Baum B (1968) Delimitation of the genus Avena (Gramineae). Can J Bot 46:121-132

Bechere E, Belay G, Mitiku D, Merker A (1996) Phenotypic diversity of tetraploid wheat landraces from northern and north-central regions of Ethiopia. Hereditas 124:165-172

Bellon MR (1996) The dynamic of crop infraspecific diversity: a conceptual frame work at the farmer level. Econ Bot 50:26-37

Bennett E (1970) Tactics in plant exploration. In: Frankel OH, Bennett E (eds) Genetic resources in plants-their exploration and conservation. Blackwell, Oxford, pp 157-179

Berg T (2009) Landraces and folk varieties: a conceptual reappraisal of terminology. Euphytica 166:423-430

Bettencourt E (2011) Chapter 8: Sources of information on existing germplasm collections. Crop GeneBank Knowledge Base. Available from http://cropgenebank.sgrp.cgiar.org/index.php? option $=$ com_content\&view $=$ article\&id $=658$

Bettencourt E, Konopka J (1990) Directory of crop germplasm collections. 3. Cereals: Avena, Hordeum, millets, Oryza, Secale, Sorghum, Triticum, Zea and pseudocereals. International Board for Plant Genetic Resources, Rome

Bettencourt E, Ford-Lloyd BV, Dias S (2008) Genetic erosion and genetic pollution of crop wild relatives: the PGR Forum perspective and achievements. In: Maxted N, Ford-Lloyd BV, Kell SP, Iriondo J, Dulloo E, Turok J (eds) Crop wild relative conservation and use. CABI, Wallingford, pp 275-284

Bommer DFR (1991) The historical development of international collaboration in plant genetic resources. In: van Hintum TJL, Frese L, Perret PM, (eds) Searching for new concepts for collaborative genetic resources management. Papers of the EUCARPIA/ IBPGR Symposium, Wageningen, The Netherlands, 3-6 December 1990. International Crop Networks Series no. 4. International Board for Plant Genetic Resources, Rome, pp 3-12

Bothmer R, von Jacobsen N (1985) Origin, taxonomy, and related species. In: Rasmusson DC (ed) Barley. American Society of Agronomists, Madison, pp 19-56

Brown AHD, Marshall DR (1995) A basic sampling strategy: theory and practice. In: Guarino L, Ramanatha Rao V, Reid R (eds) Collecting plant genetic diversity technical guidelines. CABI, Wallingford, pp 75-91

Brummitt RK, Powell CE (1992) Authors of plant names. Royal Bot Garden Kew, Kew

Brush SP (1995) In situ conservation of landraces in centres of crop diversity. Crop Sci 35:346-354 
Buerkert A, Oryakhail M, Filatenko AA, Hammer K (2006) Cultivation and taxonomic classification of wheat landraces Panjsher valley of Afghanistan after 23 years of war. Genet Resour Crop Evol 53:91-97. doi:10.1007/s10722-004-0717-3

Camacho Villa TC, Maxted N, Scholten MA, Ford-Lloyd BV (2005) Defining and identifying crop landraces. Plant Genet Resour: Charact Util 3:373-384. doi:10.1079/PGR200591

CBD (1993) Convention on Biological Diversity. Available from http:// www.cbd.int/convention/convention.shtml. Accessed July 2011

Chebotar S, Roder MS, Korzun V, Saal B, Weber WE, Börner A (2003) Molecular studies on genetic integrity of open-pollinating species rye (Secale cereale L.) after long-term genebank maintenance. Theor Appl Genet 107:1469-1476

Chwedorzewska KJ, Bednarek PT, Lewandowska R, Krajewski P, Puchalski J (2006) Studies on genetic changes in rye samples (Secale cereale L.) maintained in a seed bank. Cell Mol Biol Lett 11:338-347

Damania AB (1996) Biodiversity conservation: a review of options complementary to standard ex situ methods. Plant Genet Resour Newsl 107:1-18

Damania AB (2008) History, achievements, and current status of genetic resources conservation. Agron J 100:9-21

Day Rubenstein K, Smale M, Widrlechne MP (2006) Demand for genetic resources and the U.S. National Plant Germplasm System. Crop Sci 46:1021-1031

de Bustos A, Jouve N (2002) Phylogenetic relationships of the genus Secale based on the characterization of rDNA ITS sequences. P1 Syst Evol 235:147-154

del Greco A, Negri V, Maxted N (2007) Report of a task force on onfarm conservation and management. Second Meeting, 19-20 June 2006, Stegelitz, Germany. Bioversity International, Rome

Delipavlov D (1962) Secale rhodopaeum Delipavlov-a new species of rye from the Rhodope Mountains. Dokl Bulg AkadNauk $15: 407-411$

Demissie A, Bjornstad A (1996) Phenotypic diversity of Ethiopian barleys in relation to geographical regions, altitudinal range, and agro-ecological zones: as an aid to germplasm collection and conservation strategy. Hereditas 124:17-29

DGADR (2009) Procedimentos de inscrição no Catálogo Nacional de Variedades e de produção, certificação e comercialização de variedades de conservação de espécies agrícolas. Ministério da Agricultura, do Desenvolvimento Rural e das Pescas. DirecçãoGeral de Agricultura e Desenvolvimento Rural. DGADRDSFMMP. DSVRG-27/09

Dias S (2009) EURISCO-The European Plant Genetic Resources Search Catalogue. A vehicle to promote of the conservation and sustainable utilization of plant genetic resources. Poster abstractposter P53. At Biodiversity Information Standards (TDWG), TDWG 2009 Annual Conference, 9-13th November 2009, CORUM Conference Centre Montpellier, France

Dias S (2010) EURISCO Status. Presented at the "Meeting of the ECPGR Documentation and Information Network Coordinating Group 17-18 February 2009. Rome, Italy”. Slides. Available from http://www.ecpgr.cgiar.org/networks/documentation_information/ maccarese_2010.html

Dias SR, Gaiji S, Turok J (2006) "EURISCO- Facts and Figures". Second European Workshop on National Plant Genetic Resources Programmes: from research to policy making. November 2006. Available from (http://www2.bioversityinternational.org/Regions/ Europe/Luxembourg_Workshop/index.asp

Dias S, Dulloo ME, Arnaud E (2011) Chapter 33 - The role of EURISCO in promoting use of agricultural biodiversity. In: Maxted N, Lothar F, Iriondo J, Dulloo E, Ford-Lloyd BV, Pinheiro de Carvalho MAA (eds) Agrobiodiversity conservation: securing the diversity of crop wild relatives and landraces. CABI, Wallingford. ISBN 9781845938512)
Diederichsen A (2008) Assessments of genetic diversity within a world collection of cultivated hexaploid oat (Avena sativa L.) based on qualitative morphological characters. Genet Resour Crop Evol $55: 419-440$

Diederichsen A (2009) Duplication assessments in Nordic Avena sativa accessions at the Canadian national genebank. Genet Resour Crop Evol 56:587-597

Diulgheroff S (2006) A global overview of assessing and monitoring genetic erosion of crop wild relatives and local varieties using WIEWS and other elements of the FAO Global System on PGR. In: Ford-Lloyd BV, Dias SR, Bettencourt E (eds) Genetic erosion and pollution assessment methodologies. Proceedings of PGR Forum Workshop 5, Terceira Island, Autonomous Region of the Azores, Portugal, 8-11 September 2004. Published on behalf of the European Crop Wild Relative Diversity Assessment and Conservation Forum. Bioversity International, Rome

Dobrovolskaya O, Saleh U, Malysheva-Otto L (2005) Rationalising germplasm collections: a case study for wheat. Theor Appl Genet 111:1322-1329

Dorofeev VF, Filatenko AA, Migushova EF, Udaczin RA, Jakubziner MM (1979) Wheat. In: Dorofeev VF, Korovina ON (eds) Flora of cultivated plants, vol 1. Kolos, Leningrad

dos Santos TMM, Slaski JJ, Pinheiro de Carvalho MAA, Taylor GJ, Clemente Vieira MR (2005) Evaluation of the Madeiran wheat germplasm for aluminium resistance using aluminium-induced callose formation in root apices as a marker. Acta Physiol Plant 27:297-302

dos Santos TMM, Ganança F, Slaski JJ, Pinheiro de Carvalho MAA (2009) Morphological characterization of wheat genetic resources from the Island of Madeira, Portugal. Genet Resour Crop Evol 56:363-375. doi:10.1007/s10722-008-9371-5

EC (2008) Commission Directive 2008/62/EC of 20 June 2008. Official Journal of the European Union. L 162/13. EN. 21.6.2008

Ellstrand NC (2001) When transgenes wander, should we worry? Plant Physiol 125:1543-1545

Engels JMM, Visser L (eds) (2003) A guide to effective management of germplasm collections. IPGRI Handbooks for genebanks no. 6. IPGRI, Rome, Italy

EURISCO (2012) Available from http://eurisco.ecpgr.org. Accessed February 2012

European Wheat database (EWDB) (2012) Available from http:// www.ecpgr.cgiar.org/database/crops/wheat.htm

FAO (1996) Global plan of action for the conservation and sustainable utilization of plant genetic resources for food and agriculture. Food and Agriculture Organization of the United Nations, Rome, p 63

FAO (1998) The State of the World's Plant Genetic Resources for Food and Agriculture. Food and Agriculture Organization of the United Nations, Rome

FAO (2010) The Second Report on The State of the World's Plant Genetic Resources for Food and Agriculture. Food and Agriculture Organization of the United Nations, Rome

FAO (2011) Second Global Plan of Action for Plant Genetic Resources for Food and Agriculture. Food and Agriculture Organization of the United Nations, Rome, p 51

Farias RM, Bettencourt E (2006) Estratégia para missões sistemáticas de colheita de espécies vegetais para conservação ex situ. Editores: Instituto Nacional de Investigação Agrária e das Pescas (INIAP); Direcção Geral de Agricultura de Entre Douro e Minho (DRAEDM) pp 39

Ferreira ME (2006) Molecular analysis of genebanks for sustainable conservation and increased use of crop genetic resources. In: Ruane J, Sonnino A (eds) The role of biotechnology in exploring and protecting the agricultural resources. FAO, Rome, pp 121-127

Finkel E (2009) Scientists seek easier access to seed banks science. 12 June 2009: 1376. doi:10.1126/science.324 1376

Frankel OH, Hawkes JG (1975) Genetic resources - the past ten years and the next. In: Frankel OH, Hawkes JG (eds) Crop genetic 
resources for today and tomorrow. Cambridge University Press, Cambridge, pp 1-11

Friis-Hansen E, Sthapit B (2000) Participatory approaches to the conservation and use of plant genetic resources. International Plant Genetic Resources Institute (IPGRI), Rome

Frisvold G, Sullivan J, Raneses A (2003) Genetic improvements in major U.S. crops: the size and distribution of benefits. Agric Econ 28:109-119

Gaiji S, Dias S, Endresen DTF, Franco T (2008) Building a global accession level information system in support to the International Treaty on Plant Genetic Resources for Food and Agricultureways forward in the Americas. Recur Natur Ambient 53:126-135

Gandilyan PA (1980) Key to wheat, Aegilops, rye and barley. Academy of Science, Armenian SSR, Erevan

Guarino L (2003) Approaches to measuring genetic erosion. PGR Documentation and Information in Europe - towards a sustainable and user-oriented information infrastructure. EPGRIS Final Conference combined with a meeting of the ECP/GR Information and Documentation Network. Prague, Czech Republic, 11-13 September

Guarino L, Chadja H, Mokkadem A (1991) Wheat collecting in Southern Algeria. Short Commun Rachis Newsl, pp 23-25

Guarino L, Ramanatha Rao V, Reid R (1995) Collecting plant genetic diversity - technical guidelines. IPGRI/FAO/IUCN/UNEP, p 748

Hammer K, Gladis TH (1996) Funkionen der genebank des IPK Gatersleben bei der in situ Erhaltung on farm. Schr Genet Ressour 2:83-89

Hammer K, Spahillar M (1998) Burimet gjenetike te bimeve dhe agrobiodiversiteti. Bul Shkencave Bujqesore 3:29-36

Hammer K, Diederichsen A, Spahillar M (1999) Basic studies toward strategies for conservation of plant genetic resources pp 29-33. In: Serwinski J, Faberova I (eds) Proceedings of technical meeting on the methodology of the FAO World Information and Early Warning System on Plant Genetic Resources. FAO, Rome. Available from http://apps3.fao.org/wiews/Prague/Paper1.htm

Hanson J (1985) International Board for Plant Genetic Resources. Practical Manuals for genebanks no 1. IBPGR Secretariat, Rome

Harlan J (1975) Our vanishing genetic resources. Science 188:618-621

Harris DR (1990) Vavilov's concept of centres of origin of cultivated plants: its genesis and its influence on the study of agricultural origins. Biol J Linn Soc 39:7-16

Hawkes JG, Maxted N, Ford-Lloyd BV (2000) The ex situ conservation of plant genetic resources. Kluwer, Dordrecht

Hirano R, Kikuchi A, Kawase M, Watanabe KN (2008) Evaluation of genetic diversity of bread wheat landraces from Pakistan by AFLP and implications for a future collection strategy. Genet Resour Crop Evol 55:1007-1015

Hirano R, Jatoi SA, Kawase M, Kikuchi A, Watanabe KN (2009) Consequences of ex situ conservation on the genetic integrity of germplasm held at different genebanks: a case study of bread wheat collected in Pakistan. Crop Sci 49:2160-2166

Holubec V, Vymyslický T, Paprštein F (2010) Possibilities and reality of on-farm conservation. Czech J Genet Plant Breed 46(Special Issue):S60-S64

IBPGR (1980) A glossary of plant genetic resources terms. IBPGR Secretariat, Rome

Index Herbariorum (2012) A Global Directory of Public Herbaria and Associated Staff. [continuously updated]. Available from http:// sciweb.nybg.org/science2/IndexHerbariorum.asp. Accessed February 2012

ITPGRFA (2004) International Treaty on Plant Genetic Resources for Food and Agriculture. Available from http://www.planttreaty.org/ texts_en.htm

Jaradat AA, Shahid M, Al Maskri AY (2004) Genetic diversity in the Batini barley landrace from Oman: I. Spike and seed quantitative and qualitative traits. Crop Sci 44:304-315
Johnson RC (2008) Gene banks pay big dividends to agriculture, the environment and human welfare. PLoS Biol 6:e148

Jones H, Lister DL, Bower MA, Leigh FJ, Smith LM, Jones MK (2008) Approaches and constraints of using existing landrace and extant plant material to understand agricultural spread in prehistory. Plant Genet Resour 6:98-112. doi:10.1017/ S1479262108993138

Kaplan JK (1998) Conserving the World's plants. Agric Res 46:4-9

Kebebew F, Tsehaye Y, McNeilly T (2001) Diversity of durum wheat (Triticum durum Desf.) at in situ conservation sites in North Shewa and Bale, Ethiopia. J Agric Sci 136:383-392

Kimber G, Feldman M (1987) Wild Wheat, an introduction. Special Report 353, College of Agriculture, University of Missouri, Columbia

Kimber G, Sears ER (1987) Evolution in the genus Triticum and the origin of cultivated wheat. In: Heyne EG (ed) Wheat and wheat improvement, 2nd edn. American Society of Agronomy, Madison, pp 154-164

Knüpffer H (2009) Triticeae genetic resources in ex situ genebank collections. In: Feuillet C, Muehlbauer GJ (eds) Genetics and genomics of the Triticeae, plant genetics and genomics: crops and models 7. Springer, New York. doi:10.1007/978-0-38777489-3 2

Koo B, Pardey PG, Wright BD (2003) The economic costs of conserving genetic resources at the CGIAR centres. Agric Econ 29:287297

Ladizinsky G (1998) Plant evolution under domestication. Kluwer, Dordrecht

Leino MV, Hagenblad J (2010) Nineteenth century seeds reveal the population genetics of landrace barley (Hordeum vulgare). Mol Biol Evol 27:964-973

Li HB, Zhou MX, Liu CJ (2009) A major QTL conferring crown rot resistance in barley and its association with plant height. Theor Appl Genet 118:903-910. doi:10.1007/s10681-009-9905-8

Liston A, Rieseberg LH, Adams RP, Do N, Zhu GL (1990) A Method for collecting dried plant specimens for DNA and isozyme analyses and the results of a field test in Xinjiang China. Ann Mo Bot Gard 77:859-863

Lorenzetti F, Negri V (2009) The European seed legislation on conservation varieties. In: Veteläinen $M$, Negri V, Maxted N (eds) European landraces: on-farm conservation, management and use. Bioversity Technical Bulletin no 15. Bioversity International, Rome, pp. 287-295

Lorenzetti F, Lorenzetti S, Negri V (2009) The Italian laws on conservation varieties and the national implementation of Commission Directive 2008/62 EC. In: Veteläinen M, Negri V, Maxted N (eds) European landraces: on-farm conservation, management and use. Bioversity Technical Bulletin no 15. Bioversity International, Rome, pp. 300-304

Loskutov IG (1999) Vavilov and His Institute - a history of world collection of plant genetic resources in Russia. International Plant Genetics Research Institute, Rome, p 188

Loskutov IG (2003) Classification and diversity of the genus Avena L. In: Lipman E, Maggioni L, Knüpffer H, Ellis R, Leggett JM, Kleijer G, Faberová I, Le Blanc A Cereal Genetic Resources in Europe. Report of a Cereals Network/Report of a Working Group on Wheat, First Meeting, Yerevan, Armenia, 3-5 July 2003/ Second Meeting, 22-24 September 2005, La Rochelle, France, IPGRI, Rome, pp 85-90

Louette D (1999) Traditional management of seed and genetic diversity: what is a landrace? In: Brush SB (ed) Genes in the field: onfarm conservation of crop diversity. Lewis Publishers, CRDI/ IPGRI, pp 109-142

Löve Á (1984) Conspectus of the Triticeae. Feddes Repert 95:425-521

Mac Key J (1988) A plant breeder's perspective on taxonomy of cultivated plants. Biol Zentralblatt 107:369-379 
MADRP (2009) Portaria no. 1268/2009 de 16 de Outubro. Ministério da Agricultura, do Desenvolvimento Rural e das Pescas. Diário da República, 1. ${ }^{\text {a }}$ série — no. 201-16 de Outubro de 2009. pp. 7808-7813

Mantzavinou A, Bebeli PJ, Kaltsikes PJ (2005) Estimating genetic diversity in Greek durum wheat landraces with RAPD markers. Aust J Agric Res 56:1355-1364

Martos V, Royo C, Rharrabti Y, Garcia del Moral LF (2005) Using AFLPs to determine phylogenetic relationships and genetic erosion in durum wheat cultivars released in Italy and Spain throughout the 20th century. Field Crops Res 91:107-116. doi:10.1016/ j.fcr.2004.06.003

Maxted N, Ford-Lloyd BV, Hawkes JG (1997) Contemporary conservation strategies. In: Maxted N, Ford-Lloyd BV, Hawkes JG (eds) Plant genetic conservation: the in-situ approach. Chapman \& Hall, London, pp 20-55

Maxted N, Lothar F, Iriondo J, Dulloo E, Ford-Lloyd BV, Pinheiro de Carvalho MAA (2012). Agrobiodiversity conservation: securing the diversity of crop wild relatives and landraces. CABI, Wallingford,365 pp. ISBN: 978-1-84593-851-2

Miller AG, Nyberg JA (1995) Collecting herbarium vouchers. I-27. In: Guarino L, Ramanatha Rao V, Reid R (eds) Collecting plant genetic diversity - technical guidelines. IPGRI/FAO/IUCN/ UNEP, pp 561-573

Moragues M, Zarco-Hernandez J, Moralejo MA, Royo C (2006) Genetic diversity of glutenin protein subunits composition in durum wheat landraces [Triticum turgidum ssp. turgidum convar. durum (Desf.) MacKey] from the Mediterranean basin. Genet Resour Crop Evol 53:993-1002

Moss H, Guarino L (1995) Gathering and recording data in the field. I19. In: Guarino L, Ramanatha Rao V, Reid R (eds) Collecting plant genetic diversity - technical guidelines. IPGRI/FAO/IUCN/ UNEP, pp 367-417

Nagel M, Vogel H, Landjeva S et al (2009) Seed conservation in ex situ genebanks-genetic studies on longevity in barley. Euphytica 170:5-14

NCBI (2012) Available from http://www.ncbi.nlm.nih.gov/Taxonomy/ Browser/wwwtax.cgi?id=4513. Accessed February 2012

Negri V (2003) Landraces in central Italy: where and why they are conserved and perspectives for their on-farm conservation. Genet Resour Crop Evol 50:871-885

Nevski A (1941) Beiträge zur Kenntniss der wildwachsenden Gersten in Zusammenhang mit der Frage über den Ursprung von Hordeum vulgare L. und Hordeum distichon L. (Versucheiner Monographie der Gattung Hordeum). Trudy Eot Imr Akad Nauk SSSR 1:64-255

Newton AC, Akar T, Baresel JP, Bebeli PJ, Bettencourt E, Bladenopoulos KV, Czembor JH, Fasoula DA, Katsiotis A, Koutis K, Koutsika-Sotiriou M, Kovacs G, Larsson H, Pinheiro de Carvalho MAA, Rubiales D, Russell J, dos Santos TMM, Vaz Patto MC (2010) Cereal landraces for sustainable agriculture. A review. Agron Sust Dev 30:237-269. doi:10.1051/agro/2009032

NordGen (2012) Available from www.nordgen.org. Accessed February 2012

Painting KA, Perry MC, Denning RA, Ayad WG (1993) Guidebook for genetic resources documentation. A self-teaching approach to the understanding, analysis and development of genetic resources documentation. International Plant Genetic Resources Institute, Rome

Papadakis JS (1929) Formes Grecques de blé. Bulletin Scientifique No. 1. Station d'Amélioration des Plantes, A Salonique

Pardey PG, Koo K, Wright BD, van Dusen ME, Skovmand B, Taba S (2001) Plant genetic resources. Costing the conservation of genetic resources: CIMMYT's ex situ maize and wheat collection. Crop Sci 41:1286-1299

Parzies HK, Spoor W, Ennos RA (2000) Genetic diversity of barley landrace accessions (Hordeum vulgare ssp. vulgare) conserved for different lengths of time in ex situ gene banks. Heredity $84: 476-486$
Pecetti L, Doust MA, Calcagno L, Raciti CN, Boggini G (2001) Variation of morphological and agronomical traits, and protein composition in durum wheat germplasm from Eastern Europe. Genet Resour Crop Evol 48:609-620

Perry MC, Bettencourt E (1995) Sources of information on existing germplasm collections. I-8. In: Guarino L, Ramanatha Rao V, Reid R (eds) Collecting plant genetic diversity - technical guidelines. IPGRI/FAO/IUCN/UNEP, pp 121-129

Pinheiro de Carvalho MAA, Slaski JJ, dos Santos TMM, Ganança FT, Abreu I, Taylor GJ, Clemente Vieira MR, Popova TN, Franco E (2003) Identification of aluminium resistant genotypes among Madeiran regional wheats. Commun Soil Sci Plant Anal 34(19 \& 20):2973-2985. doi:10.1081/CSS-120025219

Pistorius R (1997) Scientists, plants and politics. A history of the plant genetic resources movement. IPGRI, Rome

Pita JM, Pfrez-Garcia F, Escudero A, de la Cuadra C (1998) Viability of Avena sativa L. seeds after 10 years of storage in base collection. Field Crops Res 55:183-187

Porceddu E, Damania AB (1992) Sampling strategies for conserving variability of genetic resources in seed crops. Technical Manual no 17. ICARDA, Aleppo

Porfiri O, Costanza MT, Negri V (2009) Landrace Inventories in Italy and the Lazio Region Case Study. In: Veteläinen M, Negri V, Maxted N (eds) European landraces: on-farm conservation, management and use. Biodiversity technical bulletin no 15 . Biodiversity International, Rome, pp 117-123

Qualset CO (1975) Sampling germplasm in the centre of diversity: an example of disease resistance in Ethiopian barley. In: Frankel OH, Hawkes JG (eds) Crop genetic resources for today and tomorrow. Cambridge University Press, Cambridge, pp 81-96

Rao NK, Hanson J, Dulloo ME, Ghosh K, Nowell D, Larinde M (2006) Manual of seed handling in genebanks. Handbook for genebanks no 8. Bioversity International, Rome, Italy

Rawashdeh NK, Haddad NI, Al-Ajlouni MM, Turk MA (2007) Phenotypic diversity of durum wheat (Triticum durum Desf.) from Jordan. Genet Resour Crop Evol 54:129-138

Reem H, Hodgkin T (2007) The use of wild relatives in crop improvement: a survey of developments over the last 20 years. Euphytica 156:1-13

Reynolds M, Dreccer F, Trethowan R (2007) Drought-adaptive traits derived from wheat wild relatives and landraces. Integrated approaches to sustain and improve plant production under drought stress. J Exp Bot 58(2):177-186

Ribeiro-Carvalho C, Guedes-Pinto H, Heslop-Harrison JS, Schwarzacher $\mathrm{T}$ (2001) Introgression of rye chromatin on chromosome 2D in the Portuguese wheat landrace 'Barbela'. Genome 44:1122-1128

Rice EB, Smith ME, Mitchell SE, Kresovich S (2006) Conservation and change: a comparison of in situ and ex situ conservation of Jala maize germplasm. Crop Sci 46:428-436

Rocha F, Bettencourt E, Gaspar C (2008) Genetic erosion assessment through the re-collecting of crop germplasm. Counties of Arcos de Valdevez, Melgaço, Montalegre, Ponte da Barca and Terras de Bouro (Portugal). Plant Genet Resour Newsl 154:6-13

Roshevitz RY (1947) A monograph of the wildweedy and cultivated species of rye. Acta Inst Bot Nomine Acad Sci USSR Ser 1 Fe Et Syst 6:105-163

Ruiz M, Aguiriano E (2004) Analysis of duplication in the Spanish durum wheat collection maintained in the CRF-INIA on the basis of agro-morphological traits and gliadin proteins. Genet Resour Crop Evol 51:231-235

Ruiz M, Martín I (1998) Spanish landraces collection of durum wheat maintained at the CRF-INIA. CIHEAM-Options Mediterraneennes 40:601-606

Ruiz M, Martín I, de la Cuadra C (1999) Cereal seeds viability after 10 years of storage in active and base germplasm collections. Field Crops Res 64:229-236 
Ruiz M, Rodriguez-Quizano M, Metakovsky EV, Vazquez JF, Carrillo JM (2002) Polymorphism, variation and genetic identity of Spanish common wheat germplasm based on gliadins alleles. Field Crops Res 79:185-196

Sackville Hamilton NR, Chorlton KH (1997) Regeneration of accessions in seed collections: a decision guide. Handbook for genebanks no 5. International Plant Genetic Resources Institute, Rome

Saker M, Adawy S, Smith CM (2008) Entomological and genetic variation of cultivated barley (Hordeum vulgare) from Egypt. Arch Phytopathol Plant Prot 41:526-536

Saxena S, Singh AK (2006) Revisit to definitions and need for inventorization or registration of landrace, folk, farmers' and traditional varieties. Curr Sci 91:1451-1454

Sencer HA, Haekes JG (1980) On the origin of cultivated rye. Biol J Linn Soc 13:299-313

SINGER (2012) Available from http://www.singer.cgiar.org/. Accessed February 2012

Smale M, Day-Rubenstein K (2002) The demand for crop genetic resources: international use of the US national plant germplasm system. World Dev 30:1639-1655

Smale M, Koo B (2003) What is a genebank worth? International Food Policy Research Institute, Biotechnology and Genetic Resource Policies. Brief 7. pp 5

Steiner AM, Ruckenbauer P, Goecke E (1997) Maintenance in GeneBanks, a case study: contaminations observed in the Nurnberg oats of 1831. Genet Resour Crop Evol 44:533-538

Swaminathan MS (2002) The past, present and future contributions of farmers to the conservation and development of genetic diversity. In: Engels JMM, Ramanatha Rao V, Brown AHD, Jackson MT (eds) IPGRI. Managing Plant Genetic Diversity. CABI, Wallingford, pp 23-31

Teklu Y, Hammer K (2009) Diversity of Ethiopian tetraploid wheat germplasm: breeding opportunities for improving grain yield potential and quality traits. Plant Genet Resour 7:1-8

Teklu Y, Hammer K, Huang XQ, Roder MS (2005) Analysis of microsatellite diversity in Ethiopian tetraploid wheat landraces. Genet Resour Crop Evol 53:1115-1126

Tesemma T, Tsegaye S, Belay G, Bechere E, Mitiku D (1998) Stability of performance of tetraploid wheat landraces in the Ethiopian highland. Euphytica 102:301-308

Torricelli R, Quintalian L, Falcinelli M (2009) The "Farro" (Triticum dicoccon Schrank) from Monteleone di Spoleto (Valnerina Valley, Umbria). In: Veteläinen M, Negri V, Maxted N (eds.) European landraces: on-farm conservation, management and use. Bioversity Technical Bulletin no 15 . Bioversity International, Rome, pp 183-186

Trethowan RM, Mujeeb-Kazi A (2008) Novel germplasm resources for improving environmental stress tolerance of hexaploid wheat. Crop Sci 48:1255-1265

Tsegaye S, Tesemma T, Belay G (1996) Relationships among tetraploid wheat (Triticum turgidum L.) landrace populations revealed by isozyme markers and agronomic traits. Theor Appl Genet 93:600-605 van Hintum TJL, Ellings A (1991) Assessment of glutenin and phenotypic diversity of Syrian durum wheat landraces in relation to their geographical regions. Euphytica 55:209-215

van Hintum TJL, Knüpffer H (1995) Duplication within and between germplasm collections. I. Identification duplication on the basis of passport data. Genet Resour Crop Evol 42:1127-1133

van Hintum TJL, Sackville Hamilton NR, Engles JMM, van Treuren R (2002) Accession management strategies: splitting and lumping. In: Engels JMM, Ramanatha Rao V, Brown AHD, Jackson MT (eds) Managing plant genetic diversity. CABI, New York, pp $113-120$

van Slageren MW (1994) Wild wheats: a monograph of Aegilops L. and Amblyopyrum (Jaub. \& Spach) Eig (Poaceae). Wageningen Agriculture University Papers, 7. Wageningen Agricultural University, Wageningen, $513 \mathrm{pp}$

van Treuren R, van Hintum TJL (2001) Identification of intraaccession genetic diversity in selfing crops using AFLP markers: Implications for collection management. Genet Resour Crop Evol 48:287-295

van Treuren R, Bas N, Goossens PJ, Jansen H, van Soest LJM (2005) Genetic diversity in perennial ryegrass and white clover among old Dutch grasslands as compared to cultivars and nature reserves. Mol Ecol 14:39-52

Vasconcelos JC (1933) Trigos Portugueses ou de há muito cultivados no País (subsídios para o seu estudo botânico). Boletim de Agricultura Ano I, (1-2 1 série), Direcção Geral de Acção Social Agrária, Lisboa

Veteläinen M, Negri V, Maxted N (2009) European landraces: on-farm conservation, management and use. Bioversity Technical Bulletin no 15 . Bioversity International, Rome

von Rümker K (1908) Die systematische Einteilung und Benen-ung der Getreidesorten für praktische Zwecke. Jahrb Dtsch landwirts Ges 23:137-167

WIEWS (2012) Available from http://apps3.fao.org/wiews/wiews.jsp. Accessed March 2012

Wood D, Lenne J (1997) The conservation of agrobiodiversity onfarm: questioning the emerging paradigm. Biodivers Conserv 6:109-129

Yonezawa K (1985) A definition of the optimal allocation of effort in conservation of plant genetic resources with application to sample size determination for field collection. Euphytica 34:345-354

Zeven AC (1998) Landraces: a review of definitions and classifications. Euphytica 104:127-139

Zeven AC (2002) Traditional maintenance breeding of landraces: 2 Practical and theoretical considerations on maintenance of variation of landraces by farmers and gardeners. Euphytica 123:147158

Zeven AC, Schachl R (1989) Groups of bread wheat landraces in Austrian Alps. Euphytica 41:235-246

Zohary D, Hopf M (2000) Domestication of plants in the old world: the origin and spread of cultivated plants in West Asia, Europe, and the Nile Valley. Oxford University Press, New York 